\title{
Vitamin C to Improve Organ Dysfunction in Cardiac Surgery Patients-Review and Pragmatic Approach
}

\author{
Aileen Hill ${ }^{1,2,3, *} \mathbb{C}^{\mathbb{D}}$, Sebastian Wendt ${ }^{3,4}$, Carina Benstoem ${ }^{1,3}$, Christina Neubauer ${ }^{1,3}$, \\ Patrick Meybohm ${ }^{5}$, Pascal Langlois ${ }^{6}$, Neill KJ Adhikari ${ }^{7}$ (i), Daren K. Heyland ${ }^{8}$ and \\ Christian Stoppe 1,3,* (iD \\ 1 Department of Intensive Care Medicine, University Hospital RWTH, D-52074 Aachen, Germany; \\ cbenstoem@ukaachen.de (C.B.); cneubauer@ukaachen.de (C.N.) \\ 2 Department of Anesthesiology, University Hospital RWTH, D-52074 Aachen, Germany \\ 3 3CARE-Cardiovascular Critical Care \& Anesthesia Evaluation and Research, D-52074 Aachen, Germany; \\ swendt@ukaachen.de \\ 4 Department of Thoracic, Cardiac and Vascular Surgery, University Hospital RWTH, \\ D-52074 Aachen, Germany \\ 5 Department of Anesthesiology and Intensive Care, University Hospital Frankfurt, \\ D-60590 Frankfurt, Germany; patrick.meybohm@kgu.de \\ 6 Department of Anesthesiology and Reanimation, Faculty of Médecine and Health Sciences, Sherbrooke \\ University Hospital, Sherbrooke, Québec, QC J1H 5N4, Canada; Pascal.laferriere-langlois@usherbrooke.ca \\ 7 Department of Critical Care Medicine, Sunnybrook Health Sciences Centre, Interdepartmental Division of \\ Critical Care Medicine, University of Toronto; Toronto, ON M4N 3M5, Canada; \\ neill.adhikari@sunnybrook.ca \\ 8 Clinical Evaluation Research Unit, Kingston General Hospital, Kingston, ON K7L 2V7, Canada; \\ dkh2@queensu.ca \\ * Correspondence: ahill@ukaachen.de (A.H.); christian.stoppe@gmail.com (C.S.); \\ Tel.: +49-241-8038166 (A.H.); +49-241-8036575 (C.S.)
}

Received: 26 June 2018; Accepted: 25 July 2018; Published: 27 July 2018 updates

\begin{abstract}
The pleiotropic biochemical and antioxidant functions of vitamin $C$ have sparked recent interest in its application in intensive care. Vitamin C protects important organ systems (cardiovascular, neurologic and renal systems) during inflammation and oxidative stress. It also influences coagulation and inflammation; its application might prevent organ damage. The current evidence of vitamin C's effect on pathophysiological reactions during various acute stress events (such as sepsis, shock, trauma, burn and ischemia-reperfusion injury) questions whether the application of vitamin C might be especially beneficial for cardiac surgery patients who are routinely exposed to ischemia/reperfusion and subsequent inflammation, systematically affecting different organ systems. This review covers current knowledge about the role of vitamin $C$ in cardiac surgery patients with focus on its influence on organ dysfunctions. The relationships between vitamin $C$ and clinical health outcomes are reviewed with special emphasis on its application in cardiac surgery. Additionally, this review pragmatically discusses evidence on the administration of vitamin $C$ in every day clinical practice, tackling the issues of safety, monitoring, dosage, and appropriate application strategy.
\end{abstract}

Keywords: vitamin C; ascorbic acid; cardiac surgery; antioxidant therapy; nutrient; oxidative stress; organ dysfunction; multi organ failure 


\section{Introduction}

\subsection{Pathogenesis of Organ Dysfunction after Cardiac Surgery}

Patients undergoing cardiac surgery experience a complex systemic inflammatory response syndrome (SIRS). SIRS after cardiac surgery is induced by surgical trauma [1,2], foreign surface contact during cardiopulmonary bypass (CPB) [2-9], CPB itself [1,9-12], ischemia-reperfusion-injury (I/R) [3,10,13], endotoxemia [3,10] and blood transfusion [10,14,15], as shown in Figure 1. Each stimulus triggers both the cellular and the humoral inflammatory response systems. Cellular mechanisms include the activation of leukocytes, platelets and endothelial cells $[2,3,10,12,13]$. Humoral reactions are mainly the activation of complement and coagulation systems, as well as the release of inflammatory mediators and reactive oxygen species $[2,5,10,13]$.

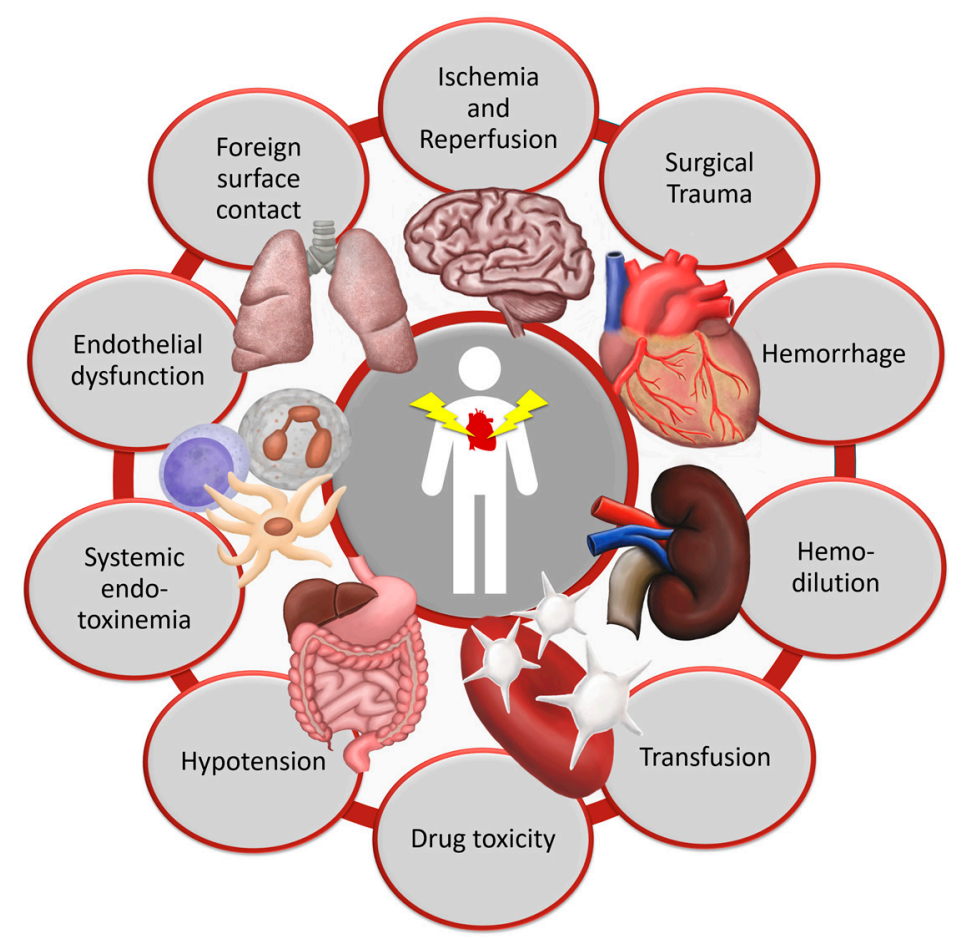

Figure 1. Pathophysiological mechanisms of organ damage in cardiac surgery.

Oxidative stress is defined as an imbalance between production of oxidants, mainly free radicals and reactive metabolites, in relation to their elimination by protective mechanisms. In many acute stages of disease, the production of reactive oxygen species (ROS) is initiated by several conditions, for example I/R-injury, activation of the Nicotinamide Adenine Dinucleotide Phosphate (NADPH) oxidase, as well as severe alterations in the mitochondrial metabolism [16]. ROS play an essential role in human biology and regulate different metabolic processes and signaling pathways. In critical illness, such as trauma, surgery, ischemia and reperfusion, shock and sepsis, the ROS production increases and often exceeds the natural antioxidant capacity, leading to damage of macromolecule structures. Structural damage of macromolecules such as proteins, nucleic acids, lipids and carbohydrates impairs their essential biological function and leads to significant damage of cell structure and organ function [17]. General activation of the inflammatory system and oxidative stress lead to leukocyte extravasation, intravascular leukostasis, lipid peroxidation, cell death, vasodilation and capillary fluid leakage in tissues, which negatively influence patient outcome [13,18-22].

While SIRS is a well-known reaction to cardiac surgery, it can cause multiple acute and persistent organ dysfunctions, which are explained in greater detail in Section 3. Postoperative complications, especially organ failure and infections, are major determinants of morbidity and mortality, necessitating 
prolonged hospital and intensive care unit (ICU) length-of-stay (LOS), which is further associated with high care-related costs and worse quality of life after cardiac surgery [2,3,10,11,23-25]. In fact, the development of acute and persistent multi-organ dysfunction occurs in $15 \%$ of patients and is the most important determinant of mortality, clinical outcome and quality of life for patients who underwent cardiac surgery $[23,25]$.

\subsection{Basic Metabolism and Functions of Vitamin C}

Vitamin $C$ is an essential micronutrient involved in numerous biochemical and biological processes. Two forms of vitamin $C$ are present in plasma: Ascorbic acid (AA) and its oxidized form dehydroascorbate (DHA). The latter contributes less than $10 \%$ to the total ascorbate in human plasma [26]. The human body is unable to synthesize vitamin $C$ due to lack of the last enzyme in the biosynthetic process. An adequate intake of vitamin C of $200 \mathrm{mg} /$ day, equaling approximately five servings of fruit and vegetables is recommended, though food content varies due to its lability [27]. Vitamin C is absorbed enterally, remains unbound in human plasma, and is dialyzable. Renal elimination of vitamin $C$ follows its glomerular filtration, if the concentration of vitamin $C$ in the urine is larger than the capacity of the responsible transport protein, which is achieved by vitamin $C$ uptake of $100 \mathrm{mg} /$ day and a plasma concentration of $60 \mu \mathrm{mol} / \mathrm{L}$ [27].

Almost complete bioavailability was calculated in several models for dosages of $200 \mathrm{mg} / \mathrm{day}$. Levine et al. observed tissue saturation of vitamin C occurring at intakes of $100 \mathrm{mg} /$ day in adult healthy adult men $[27,28]$. Tissue saturation was assessed by vitamin $C$ concentrations in lymphocytes, monocytes, and neutrophils. A steep sigmoidal relationship between vitamin $C$ dose and steady-state plasma concentration was observed, where a dose of $200 \mathrm{mg}$ produced approximately $80 \%$ plasma saturation, while plasma saturation occurred at about $1000 \mathrm{mg}$ of vitamin $\mathrm{C}$. However, the saturation of cells occurs at $100 \mathrm{mg} /$ day due to active vitamin $C$ transport, which saturates at about 60-70 $\mu \mathrm{mol} / \mathrm{L}$. The peak plasma concentration is reached about $2 \mathrm{~h}$ after ingestion, while an exponential drop of plasma levels is observed after intravenous application of vitamin $C$, where a half-life of vitamin $C$ in plasma of approximately one hour was observed [27].

Vitamin $C$ acts as an electron donor and has pleiotropic functions in the human body, being required by more than 60 enzymes. Among these, vitamin $C$ dependent reactions are the synthesis of norepinephrine, collagen and carnitine. Furthermore, vitamin $\mathrm{C}$ dependent mono- and dioxygenases are involved in peptide amidation and tyrosine metabolism [29,30]. In addition, vitamin C plays a pivotal role in the metabolism of cholesterol to bile acids and in steroid metabolism [29,30]. Besides, vitamin C is known to support the cytochrome P450 driven hydroxylation or aromatic drugs and carcinogens [30] and to promote iron absorption in the small intestine [27].

Vitamin C enhances cell differentiation from somatic cells to induced pluripotent stem cells [31,32], or from stem cells to cardiomyocytes $[33,34]$, which may be an important feature during various regenerating processes in chronically or acute critically ill patients. Previous studies have demonstrated that vitamin $C$ also acts on epigenetic mechanisms [35]. Yet, given the limited data available in the setting of acute critical illness, studies are encouraged to explore this in the near future.

Based on its redox-potential and powerful antioxidant capacity, vitamin $C$ has been called the most important antioxidant that counters the influence of free radicals [36,37]. The most relevant biochemical pathways concerning the development of organ dysfunctions are illustrated for each individual organ system in Section 2. Although important, a more comprehensive description of the underlying biochemical mechanisms and the influences of vitamin $\mathrm{C}$ are explained in greater detail elsewhere $[29,30,38-40]$.

\subsection{The Influence of Vitamin C on Oxidative Stress and Inflammation}

Vitamin C scavenges free radicals through the formation of ascorbyl radical and thereby prevents damage to macromolecules such as lipids or the DNA. The dismutation of two ascorbyl radicals produces one molecule of ascorbate and one molecule of DHA [41]. Additionally, vitamin C inhibits the 
expression of intracellular adhesion molecules and thereby inhibits the intake of immune cells into the microcirculation [41]. Furthermore, an increase of the intracellular vitamin C concentration inhibits the protein phosphatase type 2A and thereby protects the endothelial barrier from septic shock [42]. Due to its pleiotropic functions in eight enzymatic processes, vitamin C not only mitigates oxidative stress, but also restores vascular responsiveness to vasoconstrictors [43], ameliorates microcirculatory blood flow, preserves endothelial barriers [40], prevents apoptosis [44] and augments bacterial defense [40].

\subsection{Current Evidence of Vitamin C in Critically Ill Patients}

Sepsis, trauma, burn and surgery are causes of systemic inflammatory responses and can lead to similar pathologies in the human body, including microvascular dysfunction, refractory vasodilatation, endothelial barrier dysfunction, edema and disseminated intravascular coagulation [45]. Vitamin C concentrations are lowered in critical illness [46], in patients recovering from surgery [47,48], in patients after cardiac surgery [49] and especially in patients heading towards multi-organ failure [19,50]. Fowler et al observed a lower rate of organ dysfunction as assessed by the sequential organ failure assessment (SOFA) score and a reduced 28-day mortality after the application of vitamin $C$ in patients with sepsis and multi-organ-failure, whereas an influence on the ICU-LOS was not observed [51]. Zabet et al. demonstrated in 2016 patients a significantly reduced mean vasopressor demand and shorter duration of vasopressor therapy and reduced mortality in 28 septic patients receiving vitamin C [52]. In 2002, Nathens et al. observed a decreased risk of pneumonia, acute respiratory distress syndrome (ARDS) and a tendency towards lower alveolar inflammation in a randomized controlled trial (RCT) of antioxidant supplementation ( $1 \mathrm{~g}$ vitamin C and $1.000 \mathrm{IU}$ vitamin E intravenously three times per day for up to 28 days) in mostly trauma patients $(n=595)$, although the results of this RCT did not reach statistical significance [53]. In severe burn patients, ascorbic acid reduced fluid demand and increased urine production, in a retrospective review by Kahn et al. [54] and in an RCT by Tanaka et al. [55]. In fact, the application of vitamin $C$ is frequently considered in the treatment of severe burn patients [56]. While an overview of the influence of vitamin C on organ dysfunction is summarized in Table 1, Section 2 will take a closer look at each individual organ system.

Table 1. Summary of vitamin C's influence on organ systems.

\begin{tabular}{ll}
\hline \multicolumn{1}{c}{ Organ System } & \multicolumn{1}{c}{ Influence of Vitamin C } \\
\hline Nervous system & $\begin{array}{l}\text { Elevated levels protect neurons from oxidative damage [49,57] } \\
\text { Reduces the infarct volume after ischemia [58] }\end{array}$ \\
\hline \multirow{2}{*}{ Cardiovascular System } & $\begin{array}{l}\text { Attenuates myocardial damage and improves myocardial stunning [49] } \\
\text { Reduces vasopressor demand [52] } \\
\text { Reduces rate of atrial fibrillation [59,60] } \\
\text { Improves endothelial function [61,62] }\end{array}$ \\
\hline Respiratory System & $\begin{array}{l}\text { Reduces intubation time [63] } \\
\text { Decreases risk of pneumonia and alveolar inflammation [53] }\end{array}$ \\
\hline Renal System & Reduces fluid demand and increases urine production [54,55] \\
\hline \multirow{2}{*}{ Gastrointestinal System } & $\begin{array}{l}\text { Attenuates drug toxicity, decreases inflammatory reaction [64] } \\
\text { Lowers infiltration of neutrophils [64] } \\
\text { Reduces the expression of apoptosis related genes [44] }\end{array}$ \\
\hline Coagulation System & $\begin{array}{l}\text { Restores platelet function and decreases capillary plugging [43] } \\
\text { Attenuates a sepsis-induced drop of thrombocytes [43] }\end{array}$ \\
\hline Immune System & $\begin{array}{l}\text { Inhibits bacterial growth [47], enhances microbial killing [38] } \\
\text { Supports endothelial barrier function and promotes antioxidant scavenging [38] }\end{array}$ \\
\hline
\end{tabular}




\section{Influence of Vitamin C on Organ Systems in Cardiac Surgery Patients}

\subsection{Nervous System}

\subsubsection{Neuropsychological Dysfunction after Cardiac Surgery}

Brain tissue is very susceptible to oxidative damage because of its high content of polyunsaturated fatty acids and its high demand for oxygen. Neuropsychological complications are commonly seen in patients undergoing cardiac surgery, leading to a prolonged ICU stay (Figure 2). The American College of Cardiology and the American Heart Association defined two classes of neurological complications after cardiac surgery: Type I neurological deficits include stroke and transient ischemic attack, coma and fatal cerebral injury, Type II include delirium and postoperative cognitive dysfunction [65].

Cerebral ischemia due to stroke, microembolization, hypoperfusion, or hypoxemia contributes considerably to cognitive impairment. New cerebral lesions occur in about $30-50 \%$ of cardiac surgery patients, but most of them are clinically inapparent. The incidence of manifest stroke with clinical deficits is about $1-2 \%$ after low-risk heart surgery [66-70]. Contributing factors are major bleeding and transfusions of red blood cells, preoperative use of unfractionated heparin, and use of CPB [66]. Delirium is observed in a quarter and postoperative cognitive dysfunction is observed in $25-65 \%$ of all patients, while most of these patients recover within the first months $[67,71]$. Cognitive function is strongly influenced by systemic inflammation reaction, leading to increased permeability of the blood-brain barrier and cerebral edema [3]. All neuropsychological complications are associated with decreased quality of life, inability to work, loss of independence, and increased mortality [70].

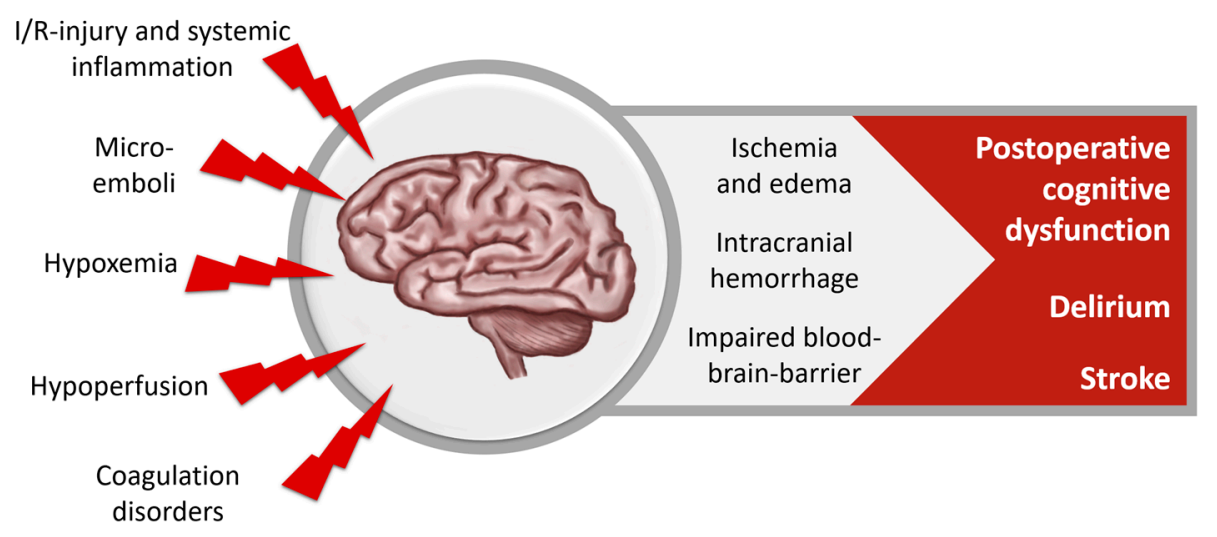

Figure 2. Cerebral dysfunction after cardiac surgery.

\subsubsection{Role of Vitamin $C$ in the Nervous System}

Vitamin C levels are elevated up to 80 times in the cells of the brain and up to four times in the cerebrospinal fluid, compared to plasma, due to its active transport via the sodium-dependent vitamin $\mathrm{C}$ transporter-2 (SVCT2) transporter [72,73], protecting neurons and leukocytes from oxidative damage [49]. Vitamin $C$ is also essential for the myelination of the neurons [74] and a vitamin C deficiency through insufficient transporter molecules leads to hypomyelination and collagen-containing extracellular matrix deficits [72]. If oxidized, vitamin C can also be taken up by glucose transporters [73]. During I/R injury or stroke, the vitamin $C$ is shifted from the intracellular to the extracellular compartment, leading to an intracellular vitamin C deficiency and perhaps neuronal damage [49].

While there is evidence that vitamin $C$ reduces infarct volume in cerebral ischemia, most evidence is derived from experimental studies inducing stroke or I/R-injury; reduced infarct volumes after experimental stroke models were demonstrated by Henry et al. [75] and Huang et al. [58]. This finding was supported by a recent study demonstrating that vitamin $C$ protects from neuronal cell death in a model of ethanol-induced damage in early development age [57]. Ethanol thereby induced the 
development of oxidative stress. Amongst others, the protection was evaluated by reduced activation of caspase- 9 and 3 as well as reduced levels of cytochrome C [57]. Lagowska-Lenard et al. found elevated antioxidant levels in the serum after vitamin $\mathrm{C}$ supplementation in a placebo-controlled RCT in patients with ischemic stroke. However, in this small study, the clinical outcome was unchanged [76].

\subsubsection{Vitamin C's Influence on the Nervous System in Cardiac Surgery Patients}

In the meta-analysis of $\mathrm{Hu}$ et al. 2017 including eight RCTs and 1060 patients, vitamin C supplementation had no effect on the incidence of stroke $(0.8 \%$ (vitamin C) vs. $2.0 \%$ (control)) in cardiac surgery patients [59]. To our knowledge, until now, no study evaluated the influence of vitamin $C$ on cognitive dysfunction or delirium in cardiac surgery patients.

\subsection{Cardiovascular System}

\subsubsection{Cardiovascular Dysfunction after Cardiac Surgery}

Surgical trauma, myocardial I/R, the excretion of inflammatory mediators, intraoperative cardioplegic arrest, reduced coronary blood flow and microvascular occlusion lead to a decline of myocardial contractility and a reduction of ventricular compliance and resulting function, as displayed in Figure 3. Vasodilation and decreased systemic vascular resistance contribute to systemic hypotension as well. Therefore, vasopressor treatment is commonly needed to support the circulation perioperatively in cardiac surgery patients. While vasopressor treatment is required to maintain adequate blood pressures, its use is associated with increased oxidative stress, endothelial dysfunction and myocardial fibrosis [77].

Myocardial dysfunction and cardiovascular insufficiency after cardiac surgery can cause a mismatch of oxygen delivery and metabolic demand and lead to tissue hypoxia. Ventricular systolic and diastolic dysfunction occurs in up to $70 \%$ of cardiac surgery patients $[78,79]$. The low cardiac output syndrome is clinically characterized by hypotension and signs of tissue hypoperfusion and occurs in 5-15\% after cardiac surgery [78,80]. Acute kidney injury (AKI) as well as neurologic and pulmonary complications are the most common consequences of low cardiac output syndrome, leading to a mortality rate of more than $20 \%[3,79,81]$. Arrhythmias are very common after cardiac surgery. Their impact on the clinical outcome depends on the kind of arrhythmia, its duration, ventricular response rate and cardiac function [82]. Arrhythmias might be I/R- and inflammation-induced and result from an increased intracellular calcium concentration due to calcium-influx through the damaged, peroxided lipids in the cell membranes, as well as hindered calcium uptake by the sarcoplasmic reticulum [49].

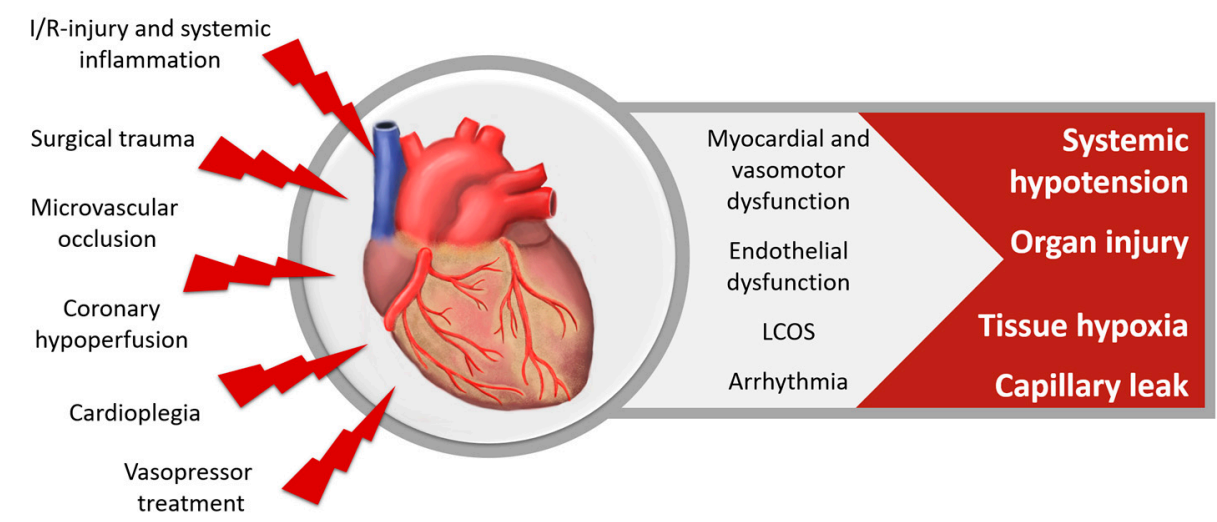

Figure 3. Cardiovascular dysfunction after cardiac surgery, LCOS = low cardiac output syndrome. 


\subsubsection{Role of Vitamin $C$ in the Cardiovascular System}

Vitamin C affects the cardiovascular system through several pathways. Despite its capability to scavenge free radicals, vitamin $C$ also promotes the differentiation of embryonic and pluripotent stem cells into cardiac myocytes [33,34]. Vitamin C has cardioprotective properties, which were demonstrated in rat models, where vitamin $C$ reduced oxidative damage in diabetic rats [83] and during I/R-injury [84]. Vitamin C improved myocardial stunning and increased left ventricular function in some animal studies, however, other animal studies showed no effect of vitamin $C$ and some only in combination with other antioxidants [49]. Therefore, preclinical data regarding the myocardial protection through vitamin C in I/R-injury remains inconclusive, as discussed in detail in a review by Spoelstra-de Man et al. [49].

Vitamin $C$ inhibits the expression of inducible nitric oxide synthetase (iNOS) in endothelial cells and neuronal nitric oxide synthetase (nNOS) and thereby lowers the plasmatic level of nitric oxide (NO), which is responsible for the activation of guanylate cyclase that counteracts the effects of vasoconstrictors. Vitamin C also prevents the impairment of vasoconstriction [43] and restores inter-endothelial electrical coupling through connexin 37-contaning gap-junctions as well as through protein kinase A-activation required for connexin 40 dephosphorylation [43]. Therefore, vitamin C might increase vasopressor-sensitivity. However, in patients with endothelial dysfunction due to cardio-metabolic diseases, such as hypertension, atherosclerosis, diabetes and smokers, vitamin $\mathrm{C}$ promotes endothelialand nitric oxide-dependent vasodilation [61]. Overall, vitamin C might improve micro-perfusion [43,47].

In extension, ascorbate also tightens the endothelial permeability barrier [61] and thus might lead to reduced extravasation and edema [85]. A meta-analysis including 44 RCTs and 1129 patients displayed an overall positive effect of vitamin $C$ on endothelial function independently of baseline plasma concentration or route of administration [62]. In the studies included in this meta-analysis, endothelial function was assessed using ultrasound, plethysmography and pulse wave analysis. The effects were significant in patients with cardio-metabolic disorders, especially with heart failure $(p<0.02)$, atherosclerosis $(p<0.001)$ and diabetes $(p<0.001)$.

\subsubsection{Vitamin C's Influence on the Cardiovascular System in Cardiac Surgery Patients}

In cardiac surgery with $\mathrm{CPB}$, vitamin $\mathrm{C}$ levels decrease with the production of ROS and remain low for days after surgery [49], indicating a greater demand of vitamin $C$ in the setting of surgery and I/R-induced oxidative stress. Oxidative stress and myocardial damage after cardiac surgery with CPB might be decreased by the administration of vitamin C, as demonstrated in an RCT by Dingchao et al. in the 1990s [86]. In this RCT including 85 patients, the intervention group received a total of $250 \mathrm{mg} / \mathrm{kg}$ vitamin C before and after CPB. Markers for myocardial injury creatine kinase (CK) and creatine phosphokinase isoenzyme muscle/brain (CK-MB), as well as malondialdehyde as a marker for oxidative stress were significantly lower in patients receiving vitamin C. Clinically, the cardiac index was higher, and the intervention-group patients were less likely to need defibrillation after weaning from cardiopulmonary bypass and had shorter ICU- and hospital-LOS [86].

Vitamin $C$ treatment also improves ventricular function, reduces vasopressor and fluid demand [86,87] and increases the cardiac index. In a systematic review [88] and in 6 different meta-analyses including 8-15 RCTs [59,60,63,89-91], vitamin C was shown to significantly reduce the occurrence of postoperative cardiac arrhythmia, mainly atrial fibrillation (AF). However, the results of these meta-analyses might be strongly influenced by publication bias, as discussed by Hemilae [92]. While postoperative AF gained increasing attention over the past years, and was investigated by several RCTs and meta-analyses, to our knowledge, no large, multicenter study evaluated the effect of vitamin $C$ on other important outcomes, such as myocardial function or vasopressor and fluid-demand. 


\subsection{Respiratory System}

\subsubsection{Pulmonary Dysfunction after Cardiac Surgery}

Pulmonary dysfunction (Figure 4) occurs in up to $79 \%$ of patients after cardiac surgery, ranging from mild subclinical functional changes to acute respiratory distress syndrome (ARDS) in less than $2 \%$ of patients [93]. Acute lung injury is characterized by inflammation, and tissue damage is dealt mainly through oxidative stress and free radicals [94]. ROS like nitric oxide and superoxide can nitrate and oxidize key amino acids in lung proteins, such as surfactant protein, disturbing their function [95].

Factors contributing to pulmonary dysfunction are poor lung mechanics, increased intrapulmonary shunt and vascular resistance, pulmonary edema, changes in surfactant and alveolar protein accumulation. The underlying pathomechanisms include inflammation and free radicals, I/R-injury, transfusion-associated lung injury and drug toxicity. Pulmonary dysfunction causes prolonged need for mechanical ventilation, increases ICU- and hospital-LOS and mortality, and significantly affects long-term physical and psychological morbidity [3,96-100].

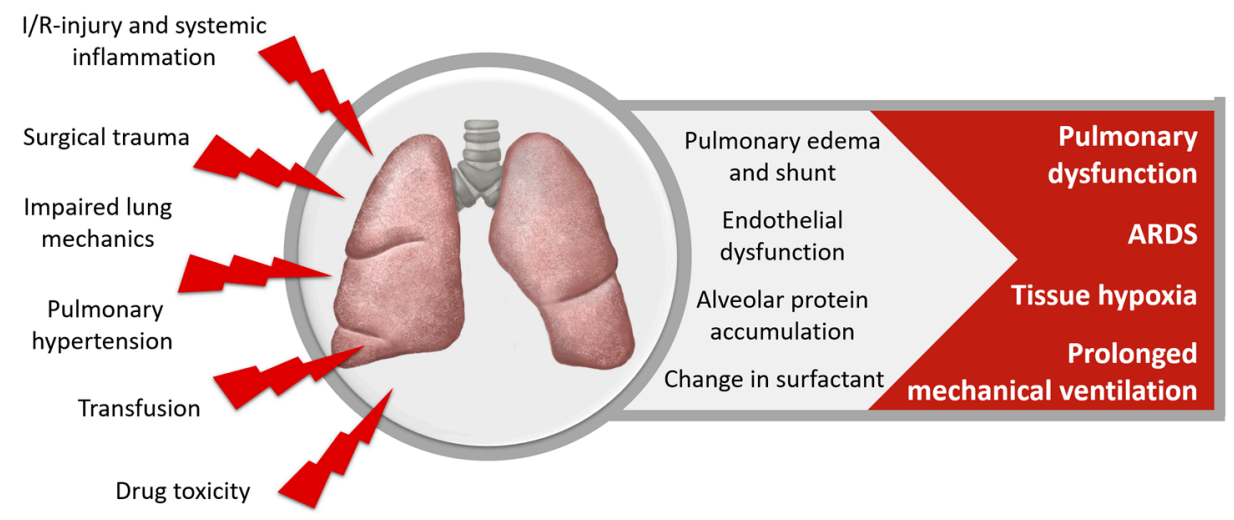

Figure 4. Pulmonary dysfunction after cardiac surgery.

\subsubsection{Role of Vitamin $C$ in the Respiratory System}

Vitamin $C$ functions as an antioxidant, preventing ROS-induced lung damage and rapid oxidation of ascorbate occurs during acute inflammation in acute lung injury [95]. In a mouse-model, the supplementation of vitamin $C$ preserved lung barrier function and functionality of ion pumps in the alveolar epithelium [101] and decreased the lung pathology in an in vivo study of influence virus infected mice [102]. In rats, vitamin C attenuated lung injury caused by I/R [103].

A study conducted in 2016 found that vitamin C treatment of human bronchial epithelial cells attenuates particulate matter induced ROS damage, IL-6 expression and increased cell viability [104]. Vitamin C additionally attenuated smoking induced pulmonary emphysema and vascular remolding by reducing ROS induced protein oxidation [105]. In a study by Nathens et al. in 2002, the application of vitamin $C$ decreased risk for pneumonia and ARDS with lower alveolar inflammation in a cohort of 270 mostly trauma patients [53]. Even though the results of this RCT did not reach statistical significance, they sparked further investigations on the subject. In the OMEGA study, Rice et al. supplemented antioxidant cocktails to ARDS patients and observed no benefit [106]. However, these cocktails contained many components and the $2 \mathrm{~g} /$ day vitamin $\mathrm{C}$ was only a minor component. In an RCT by Gadek et al., a combination of antioxidants, including vitamin C, decreased pulmonary inflammation and showed beneficial effects on gas exchange and requirement of mechanical ventilation in patients with ARDS [107]. 


\subsubsection{Vitamin C's Influence on the Respiratory System in Cardiac Surgery Patients}

Even if preclinical and clinical data seem promising, only very few studies addressed the effect of vitamin $C$ on pulmonary dysfunction in cardiac surgery. To our knowledge, the duration of mechanical ventilation was the only outcome parameter measured in RCTs investigating this matter. Reduced intubation time after cardiac surgery was shown in a meta-analysis including 3 RCTs and 575 patients (mean difference: $-2.41,95 \%$ confidence interval $-3.82 /-0.98, p=0.001$ ). However, the heterogeneity of the included trials was high $(p=0.74)$ [63].

\subsection{Renal System}

\subsubsection{Renal Dysfunction after Cardiac Surgery}

Acute kidney injury (AKI) is clinically one of the most significant organ dysfunction and occurs in about $28 \%$ of cardiac surgery patients [108], with $2-5 \%$ of patients requiring dialysis. Contributing factors are oxidative stress during renal I/R-injury, inflammation, hemolysis, cholesterol emboli, nephrotoxic drugs and toxins resulting in glomerular and tubular damage, reduced glomerular filtration rates and impaired creatinine clearance, as shown in Figure 5. AKI is strongly associated with the need for renal replacement therapy, increased hospital- and ICU-LOS, mortality and decreased long-term quality of life [3,108-114].

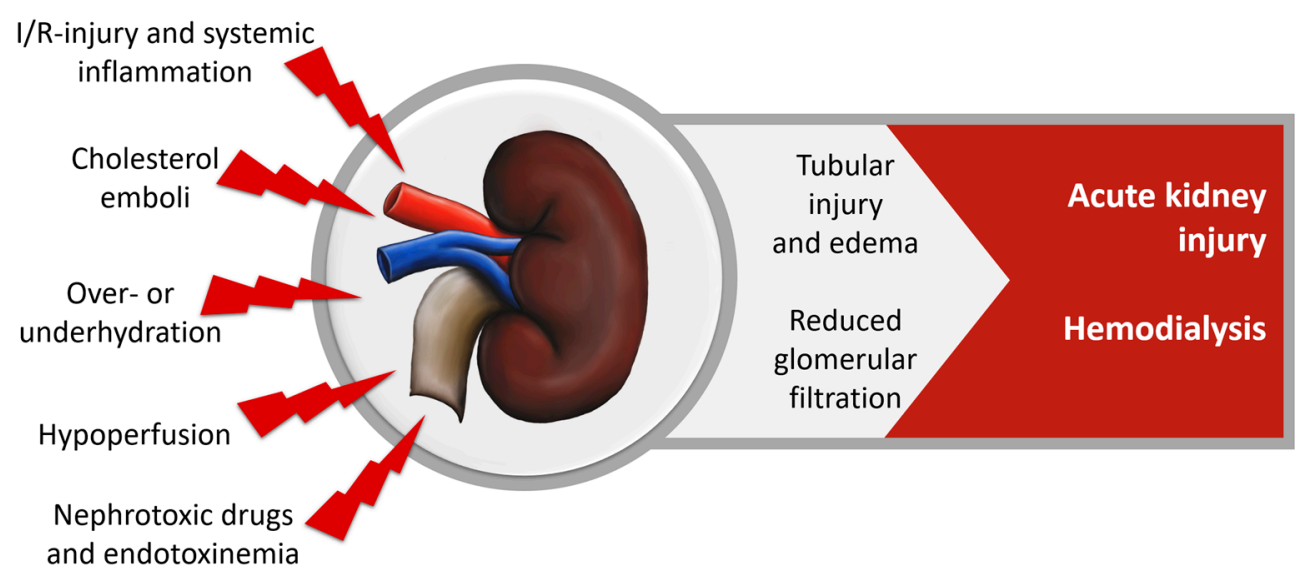

Figure 5. Renal dysfunction in cardiac surgery.

\subsubsection{Role of Vitamin $C$ in the Renal System}

The protective properties of vitamin $C$ on the renal system are also attributed to its anti-oxidant capabilities. Vitamin $\mathrm{C}$ administration reduced serum creatinine levels in patients who experienced contrast-mediated nephropathy after coronary angiography [115]. These findings were supported by a meta-analysis including 1.536 patients in 9 RCTs in 2013 by Sadat et al., decreasing risk for AKI by 33\% (risk ratio 0.672 , confidence interval 0.466-0.969, $p=0.034$ ) [116]. In contrast, excessive and long-term vitamin C consumption might lead to oxalate nephropathy. In a case report in 2012, Gurm et al. described a woman who consumed 3-6.5 g of vitamin C daily [117]. A similar case was reported in 2015: A 96-year-old woman was also diagnosed with oxalate nephropathy resulting from excessive vitamin $\mathrm{C}$ intake [118]. The tubular injuries are thereby caused by crystalline deposits of calcium oxalate, which might be metabolized from vitamin C. Therefore, the recurring formation of kidney stones, as well as chronic renal failure and hyperoxaluria are contraindications for a high-dose long-term vitamin $C$ therapy, even though adverse effects seem unlikely in short-term administration $[27,49]$. In an RCT study including burn patients, decreased volume requirement for fluid resuscitation, as well as increased urine output were observed [55]. 


\subsubsection{Vitamin C's Influence on the Renal System in Cardiac Surgery Patients}

A pilot study by Antonic et al. in 2017 with 100 on-pump coronary artery bypass graft (CABG) surgery patients was not able to confirm the assumed benefits of vitamin $C$ on renal function [119]. Potential causes for the insignificance of the results might be a rather low dosage and oral administration of vitamin $C(2 \times 1 \mathrm{~g} /$ day $)$, as discussed in greater detail in Section 5.2. In any case, further research is warranted to investigate the effect of a high-dosage intravenous vitamin $C$ application, to fully achieve the antioxidant and possibly nephroprotective effects.

\subsection{Gastrointestinal System}

\subsubsection{Gastrointestinal Dysfunction after Cardiac Surgery}

Gastrointestinal (GI) complications (Figure 6) occur in $0.2-4 \%$ [120], while a postoperative gastrointestinal atony is observed in most cardiac surgery patients [121,122]. Inflammation and I/R-injury increase GI permeability and can lead to bacterial translocation and systemic endotoxemia. The most common GI complications are postoperative ileus and GI hemorrhage, while mesenteric ischemia and intestinal perforation are GI complications with the highest mortality. GI complications increase LOS and mortality [3,10,123-125].

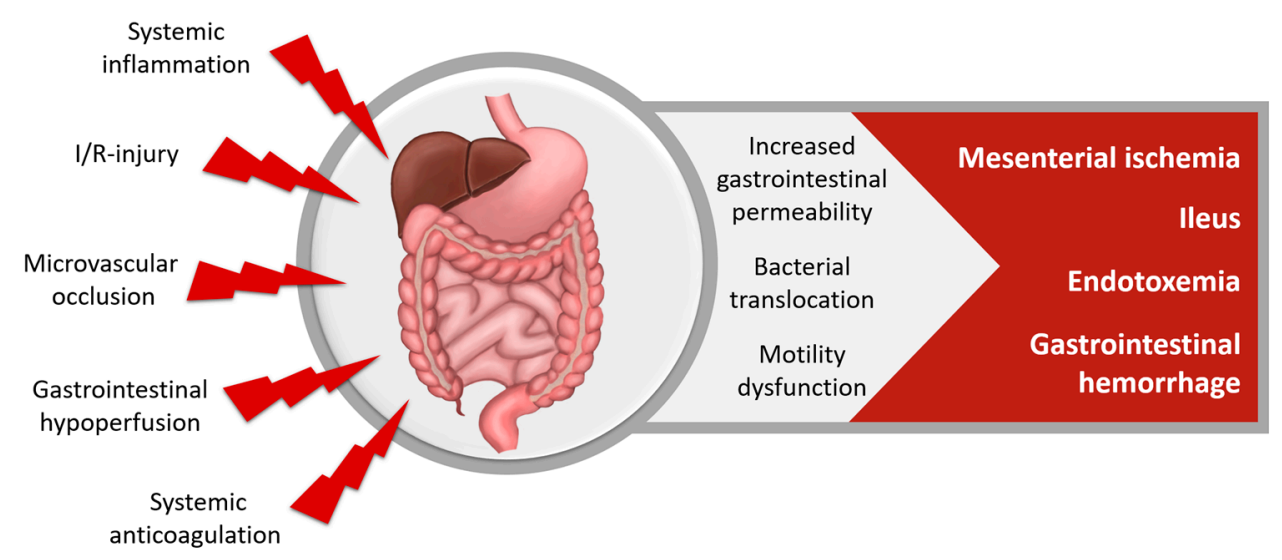

Figure 6. Gastrointestinal dysfunction after cardiac surgery.

\subsubsection{Role of Vitamin $C$ in the Gastrointestinal System}

The few available studies on the interaction of vitamin C with the GI system are derived from oncology. Vitamin C treatment might mitigate GI adverse effects associated with cancer treatment [126], where chemotherapy is often associated with damage to the mucous membrane. Al-Asmari et al. found attenuated toxicity of the antineoplastic drug 5 fluorouracil when vitamin $C$ was administered, demonstrated by decreased activation of nuclear factor kappa-light-chain-enhancer of activated $\mathrm{B}$ cells (NF-KB) and cyclooxygenase-2 expression as well as lower infiltration of neutrophils [64]. The authors suggested that the observed benefits were due to the antioxidative effects of vitamin C. Similar findings were observed by Yamamoto et al. in 2010, who showed that vitamin C treatment attenuated the expression of apoptosis related genes as well as DNA damage in crypt cells caused by radiation [44].

\subsubsection{Vitamin C's Influence on the Gastrointestinal System in Cardiac Surgery Patients}

To our knowledge, no study of vitamin $C$ in cardiac surgery reported beneficial or adverse effects on the GI system. 


\subsection{Coagulation System}

\subsubsection{Coagulation Disorders after Cardiac Surgery}

Coagulation disorders-both prothrombotic activity and coagulopathy-have deleterious effects on patient outcome (Figure 7). I/R induces the production of ROS by platelets and other vascular sources. ROS can alter platelet function and increase platelet aggregation and thrombus formation [127,128]. In a vicious circle, ROS-production and platelet-activation augment each other. Therefore, ROS may act prothrombotic. Additionally, reduced NO-responsiveness of the platelets might promote adhesion of the platelets to the endothelium, which is associated with increased cardiovascular morbidity in patients with acute coronary syndrome [127]. On the other hand, intraand postoperative coagulopathy, commonly observed after cardiac surgery, lead to an increased need for transfusion of blood products and surgical re-exploration. The definition of bleeding is still debated [129], but mild bleeding occurs in almost one fifth and major bleeding in 3-12\% of cardiac surgery patients [130]. A mean blood volume of $470 \mathrm{~mL}$ is lost during the first $12 \mathrm{~h}$ after cardiac surgery [131]. Contributing factors to coagulopathy are consumption and dilution of platelets and coagulation factors and heparinization during $\mathrm{CPB}$, as well as effects of preoperative drugs and preexisting anemia and low fibrinogen-levels. The transfusion of the allogeneic blood products is associated with inflammation, transfusion-associated lung- and kidney injury and increases risk of stroke [66]. Overall, coagulopathy and major bleeding increase the risk of stroke, acute kidney injury, infections, surgical reoperation, LOS and mortality [130-132].

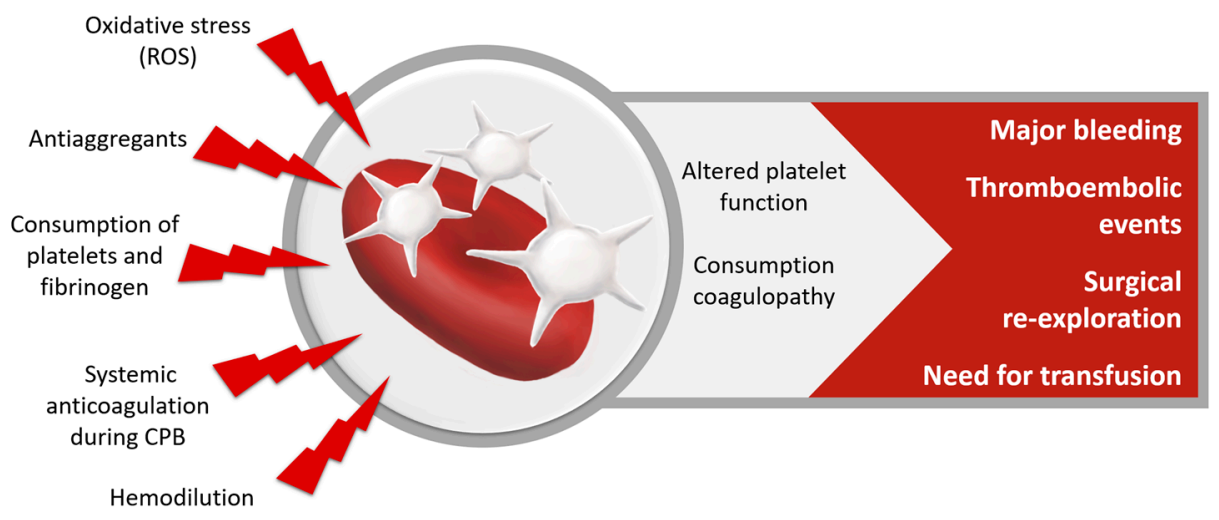

Figure 7. Coagulation disorders after cardiac surgery.

\subsubsection{Role of Vitamin C in the Coagulation System}

Vitamin $C$ has a tremendous impact on cellular and plasmatic hemostasis in the human body and has both pro- and anticoagulatory effects. The interaction between coagulation and vitamin $\mathrm{C}$ supplementation was already discussed in the early 1960s by Dayton and Weiner [133].

On a cellular level, antioxidants such as vitamin C may inhibit platelets by scavenging ROS, disrupting the vicious circle of ROS-platelet-activation, and restoring normal platelet function [127]. In healthy individuals, prostacyclin and NO prohibit platelet activation and prevent thrombosis. Vitamin C, however, inhibits the expression of iNOS in endothelial cells and nNOS in neurons and thereby lowers the plasmatic level of NO [43], hence acting pro-coagulatory. However, vitamin C also prevents microthrombus formation through inhibition of thrombin-induced and P-selectin mediated platelet aggregation and platelet-endothelial adhesion [43]. Even after the onset of microthrombus formation, ascorbate injection reverses capillary plugging and platelet-endothelial adhesion [43]. Vitamin C also inhibits the $\mathrm{pH}$-dependent thrombin-induced release of plasminogen-activator-inhibitor- 1 from platelets [43].

Plasmatic coagulation is influenced by vitamin $C$ via several pathways. ROS and other stimuli activate NF- $\kappa$ B. The transcription factor NF- $\kappa$ B initiates the expression of cytokines and proteins involved in 
coagulation, such as tissue factor [134]. This suggests that coagulation via NF- $\mathrm{kB}$ can be affected by vitamin C $[135,136]$. Furthermore, vitamin C decreases tissue plasminogen activator and von Willebrand-factor, demonstrating an important link between inflammation, coagulation and vitamin C [136,137]. Vitamin C is also known to restore the capacity for endogenous, endothelium-dependent fibrinolysis in smokers [138].

On a systemic level, the influence of vitamin $C$ on hemostasis might be dose-dependent. While depleted vitamin $C$ levels are associated with gastrointestinal hemorrhage, especially in patients undergoing acetylsalicylate-treatment [139], in very high dosages $(0.5-1 \mathrm{~g} / \mathrm{kg})$, vitamin $C$ was found to promote the occurrence of thrombosis through pro-coagulant activation of erythrocytes in a rat model [140]. Vitamin C abolished coagulation abnormalities in septic mouse blood [101] and attenuated a sepsis-induced drop of thrombocytes in the systemic blood in septic patients [43].

\subsubsection{Vitamin C's Influence on the Coagulation System in Cardiac Surgery Patients}

To our knowledge, only two studies of vitamin $C$ in cardiac surgery have addressed the issue of hemostasis. In one RCT from Sadeghpour et al. $(n=290)$, vitamin C reduced chest tube bleeding [141], while no difference was shown in another RCT [87]. Clearly, further research is needed to determine the influence of vitamin $C$ on blood loss, need for transfusion and risk of thromboembolic events and to translate biochemical pathways into clinically relevant outcomes.

\subsection{Immune System}

\subsubsection{Immune Dysfunction after Cardiac Surgery}

After cardiac surgery, infections are the most common non-cardiac complication [142], (Figure 8). A quarter of all patients undergoing high-risk heart-surgery are diagnosed with a postoperative infection [143], and nearly 5\% experience major infection. Pneumonia is the most frequent nosocomial infection in half of these cases. Surgical site infections and catheter- and device-associated infections each make up $25 \%$ of infections $[143,144]$. Major infections have a tremendous effect on subsequent survival and are associated with longer mechanical ventilation, ICU- and hospital stay and a higher morbidity and mortality up to five years after the operation [93,142-152].

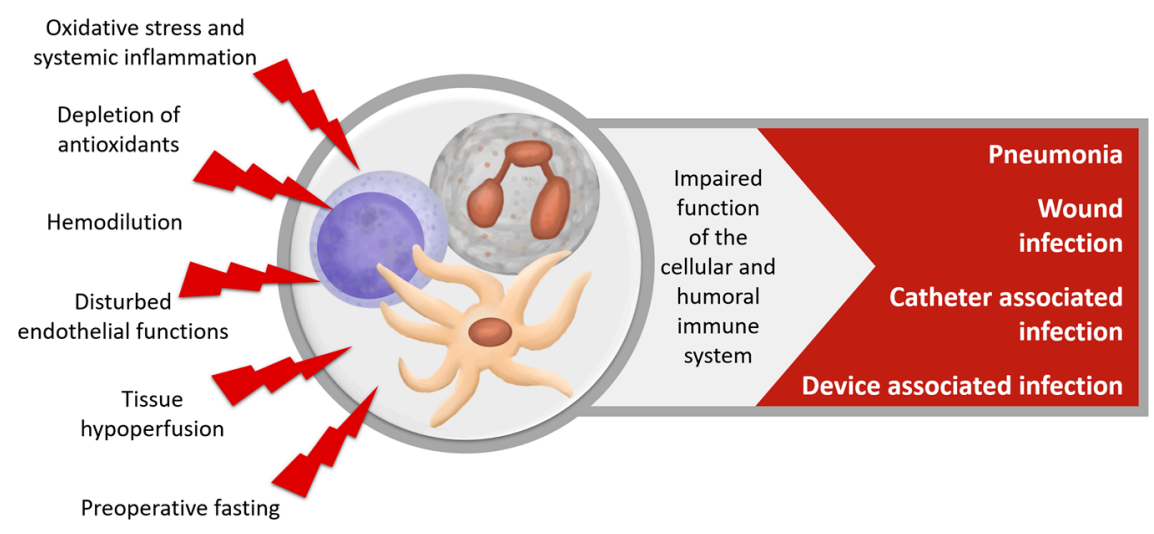

Figure 8. Dysfunction of the immune system after cardiac surgery.

\subsubsection{Role of Vitamin C in the Immune System}

Infections are associated with and accompanied by an increase of oxidative stress. The increased ROS production during infection, and hypermetabolic vitamin $\mathrm{C}$ requirements are the reasons for the observed vitamin C reduction $[38,153]$. Evidence regarding increased vitamin $C$ requirements in critical illness and after surgery will furthermore be discussed in Section 5.2.1.

Vitamin $C$ is actively accumulated into the dermal cells and neutrophils via the sodium-dependent vitamin C transporters (SVCT). Neutrophils further increase their intracellular vitamin C concentration 
through uptake of DHA via glucose transporters (GLUT) and metabolization to ascorbate [38]. The accumulation of vitamin $C$ in phagocytotic cells can enhance chemotaxis, phagocytosis, generation of ROS and microbial killing. Vitamin C is also necessary for apoptosis and the clearing of spent neutrophils from the infected site and enhances the proliferation and differentiation of $\mathrm{B}$ and T-cells, as well as antibody levels [38]. Vitamin C deficiency results in impaired immunity and thus, higher susceptibility for infections.

Vitamin C supports endothelial barrier function against pathogens and promotes antioxidant scavenging activity of the skin. Vitamin $C$ is a known inhibitor of bacterial growth, such as S. aureus and intestinal bacteria. One possible mechanism for the antibacterial function of vitamin $\mathrm{C}$ is the production of hydrogen peroxide during its oxidation [47]. Vitamin C also shortens time for wound healing through stimulation of proliferation, differentiation and migration of keratinocytes and fibroblasts, as well as through the stimulation of lipid synthesis [38]. Vitamin C enhances microbial killing through improved immune cells chemotaxis, motility and phagocytosis, and decreases necrosis through facilitation of apoptosis and clearance [38].

However, increased ROS production by the immune system is an important response to invasive pathogens. Therefore, suggesting that the radical-scavenging role of vitamin $C$ is solely beneficial remains a matter of debate and is most likely dose-dependent. The systemic effect of vitamin $C$ on bacterial and viral infections needs further research; current evidence demonstrates that vitamin $C$ might prevent the development (or help ameliorate) of the clinical course of pneumonia [154,155]. Vitamin C deficiency was associated with increased inflammation as measured in CRP, and patients with septic shock were deficient in vitamin C in $40 \%$, as observed in a study by Carr et al. [46].

\subsubsection{Vitamin C's Influence on the Immune System in Cardiac Surgery Patients}

Unfortunately, again, there is little knowledge about the influence of vitamin $C$ on postoperative immune function and infections in cardiac surgery. Sadeghpour et al. reported a significant reduction in composite outcome "complications", defined as death, infection, impairment in renal function and need for reoperation [141]. Neither the incidence of infection nor the influence of infection on the combined outcome parameter were reported in this study. Jouybar 2012 et al. [156] showed no difference in white blood count and inflammatory mediators using two bolus dosages of $3 \mathrm{~g}$ of vitamin C, 12-18 h before surgery and during CPB initiation.

\section{Influence of Vitamin C on the Overall Clinical Outcome of Cardiac Surgery Patients}

Considering the above-mentioned evidence and the data gained from meta-analyses and RCTs, as listed in Tables 2 and 3, vitamin C may have positive effects on many vital functions and organ systems, which overall may have beneficial effects on patients' short, mid and long-term outcomes.

- The overall effect is reflected by a reduced ICU-LOS in a meta-analysis of Geng et al. including 12 RCTs and 1584 patients [63] and Baker et al., including 11 RCTs and 1390 patients [89].

- $\quad$ Reduced hospital LOS was demonstrated in a systematic 2014 review including 5 RCTs [88], as well as the meta-analyses of Geng [63] and Baker [89] and Shi et al., including 13 trials involving 1956 patients [90]. However, in the meta-analysis by Hu et al. including 8 RCTs and 1060 patients, vitamin C application was not associated with reductions in ICU or hospital-LOS [59].

- Vitamin C might also reduce intubation time and postoperative complications as found by the meta-analyses of $\mathrm{Hu}$ and Shi $[63,90]$.

Effects on LOS in un-blinded studies are subject to performance bias due to co-interventions or differentially applied policies on discharge. Additionally, none of the available RCTs included in these meta-analyses was adequately powered to detect an influence of vitamin $C$ on overall clinical outcomes, such as on LOS or mortality, as discussed by Polymeropoulos et al. [60]. All meta-analyses found significant clinical and methodological heterogeneity of the included studies, limiting the strength of inferences. Therefore, there is an urgent need for additional large and well-designed clinical trials. 
Table 2. RCTs investigating the effects of vitamin C (Vit C) in cardiac surgery.

\begin{tabular}{|c|c|c|c|c|}
\hline Author and Year & Patients & Dosage of Vitamin C & p.o./i.v. & Results \\
\hline Knodell 1981 [157] & $175+$ hepatitis & $\begin{array}{l}\text { Preop: } 4 \times 800 \mathrm{mg} / \text { day for } 2 \text { days } \\
\text { Postop: } 4 \times 800 \mathrm{mg} / \text { day for } 2 \text { weeks }\end{array}$ & p.o. & Elevations of plasma vitamin $C$, no influence on the hepatitis \\
\hline Li 1990 [158] & 20 & Preop: $250 \mathrm{mg} / \mathrm{kg}$ before the start of extracorporeal circulation & N.A. & Sign. reduction in lipid peroxidation \\
\hline Dingchao 1994 [86] & $85 \mathrm{CPB}$ & $125 \mathrm{mg} / \mathrm{kg} 30 \mathrm{~min}$ before surgery and at the end of $\mathrm{CPB}$ & i.v. & $\begin{array}{l}\text { Decreased CK/CKMB, LDH, \& rate of defibrillation, ICU- and } \\
\text { hospital LOS, improved CI }\end{array}$ \\
\hline Carnes 2001 [159] & 86 CABG & $\begin{array}{l}\text { Preop: } 1 \times 2 \mathrm{~g} \text { the night before } \\
\text { Postop: } 2 \times 0.5 \mathrm{~g} / \text { day for } 5 \text { days }\end{array}$ & N.A. & Lower rate of $\mathrm{AF}$ \\
\hline Demirag 2001 [160] & 30 elective & $\begin{array}{l}\text { Group 1: } 2 \times 50 \mathrm{mg} / \mathrm{kg} \text { vitamin } C \text { at induction and end of CPB } \\
\text { Group 2: vitamin C + diltiazem: bolus and } 2 \mu \mathrm{g} / \mathrm{kg} / \mathrm{min} \text { until end of CPB }\end{array}$ & i.v. & $\begin{array}{l}\text { Prevention of lipid peroxidation no difference in myocardial } \\
\text { I/R-injury }\end{array}$ \\
\hline Eslami 2007 [161] & $100 \mathrm{CABG}$ & $\begin{array}{l}\text { Preop: } 1 \times 2 \mathrm{~g} \text { night before } \\
\text { Postop: } 2 \times 1 \mathrm{~g} / \text { day for } 5 \text { days }\end{array}$ & p.o. & Lower rate of $\mathrm{AF}$ \\
\hline Colby 2011 [162] & $24 \mathrm{CABG}$ and/or valve & $\begin{array}{l}\text { Preop: } 1 \times 2 \mathrm{~g} \text { night before } \\
\text { Postop: } 2 \times 0.5 \mathrm{~g} / \text { day for } 4 \text { days }\end{array}$ & p.o. & $\begin{array}{l}\text { No difference in CRP, WBC, fibrinogen, Trend: decreased AF, } \\
\text { hospital- and ICU-LOS }\end{array}$ \\
\hline Papoulidis 2011 [163] & 170 CABG & $\begin{array}{l}\text { Preop: } 1 \times 2 \mathrm{~g} 3 \mathrm{~h} \text { prior to surgery } \\
\text { Postop: } 2 \times 0.5 \mathrm{mg} / \text { day for } 5 \text { days }\end{array}$ & i.v. & Sign. lower rate of AF, hospital- and ICU-LOS \\
\hline Bjordahl 2012 [164] & 185 CABG & $\begin{array}{l}\text { Preop: } 1 \times 2 \mathrm{~g} \text { night before surgery } \\
\text { Postop: } 2 \times 1 \mathrm{~g} / \text { day for } 5 \text { days }\end{array}$ & p.o. & No difference in postoperative complications, mortality or $\mathrm{AF}$ \\
\hline Jouybar 2012 [156] & 40 CABG & Preop: $2 \times 3 \mathrm{~g} 12-18 \mathrm{~h}$ before surgery and during $\mathrm{CPB}$ initiation & i.v. & $\begin{array}{l}\text { No difference in inflammatory cytokines, hemodynamics, blood } \\
\text { gases, urea nitrogen, creatinine, WBC, platelet counts \& outcomes }\end{array}$ \\
\hline Dehghani 2014 [165] & $100 \mathrm{CABG}$ & $\begin{array}{l}\text { Preop: } 1 \times 2 \mathrm{~g} \\
\text { Postop: } 2 \times 0.5 \mathrm{~g} / \text { day for } 5 \text { days }\end{array}$ & p.o. & Sign. lower rate of AF, hospital- and ICU-LOS \\
\hline Ebade 2014 [166] & 40 & $\begin{array}{l}\text { Preop: } 1 \times 2 \mathrm{~g} \\
\text { Postop: } 1 \times 1 \mathrm{~g} 12 \mathrm{~h} \text { after surgery, } 3 \times 1 \mathrm{~g} \text { for } 6 \text { days after surgery }\end{array}$ & i.v. & $\begin{array}{l}\text { Lower incidence of AF } \\
\text { Shortened ICU- and hospital-LOS }\end{array}$ \\
\hline Sama-dikhah 2014 [167] & $120 \mathrm{CABG}$ & $\begin{array}{l}\text { Preop: } 1 \times 2 \mathrm{~g} \\
\text { Postop: } 1 \times 1 \mathrm{~g} / \text { day for } 5 \text { days } \\
\text { Plus atorvastatin } 40 \mathrm{mg}\end{array}$ & p.o. & Sign. lower rate of AF \\
\hline Sadegh-pour 2015 [141] & 290 CABG, valve & $\begin{array}{l}\text { Preop: } 1 \times 2 \mathrm{~g} \text { before surgery } \\
\text { Postop: } 1 \times 1 \mathrm{~g} / \text { day for } 4 \text { days }\end{array}$ & $\begin{array}{l}\text { Preop: i.v. } \\
\text { Postop: p.o. }\end{array}$ & $\begin{array}{l}\text { Sign. reductions in AF, hospital-LOS, intubation time, complications } \\
\text { (death, renal function, infection) and drainage, unchanged ICU-LOS }\end{array}$ \\
\hline Das 2016 [168] & 70 elective low risk CABG & Preop: $2 \times 0.5 \mathrm{~g}$ for 7 days prior to surgery & p.o. & $\begin{array}{l}\text { Lower vasopressors-demand, no difference in time to extubation, } \\
\text { ICU- and hospital-LOS, mortality or complications }\end{array}$ \\
\hline Antonic 2016 [169] & 105 CABG & $\begin{array}{l}\text { Preop: } 2 \times 2 \mathrm{~g}: 24 \text { and } 2 \mathrm{~h} \text { before surgery } \\
\text { Postop: } 2 \times 1 \mathrm{~g} / \text { day for } 4 \text { days }\end{array}$ & i.v. & Trend: decreased rate of AF, no difference in complications \\
\hline Antonic 2017 [119] & $100 \mathrm{CABG}$ & $\begin{array}{l}\text { Preop: } 2 \times 2 \mathrm{~g}: 24 \text { and } 2 \mathrm{~h} \\
\text { Postop: } 2 \times 1 \mathrm{~g} / \text { day for } 5 \text { days }\end{array}$ & i.v. & $\begin{array}{l}\text { No sign. protective effect of ascorbic acid on the incidence of } \\
\text { postoperative AKI }\end{array}$ \\
\hline
\end{tabular}

$\mathrm{CPB}=$ cardiopulmonary bypass, $\mathrm{CABG}=$ coronary artery bypass graft, p.o. $=$ per os, i.v. $=$ intravenous, sign. $=$ significantly, N.A. $=$ not available, $\mathrm{WBC}=$ white blood count, preop $=$ before surgery, postop = after surgery, $\mathrm{LDH}=$ lactate dehydrogenase. 


\section{Vitamin C in Combination with other Antioxidant Therapies}

Vitamin $C$ has been combined with other antioxidant substances to minimize oxidative damage, as well as with anti-arrhythmic drugs such as beta-blockers and diltiazem to reduce the incidence of postoperative cardiac arrhythmia. In combination with beta-blockers, the incidences of AF and ICU-LOS were significantly reduced compared to CABG-patients who only received beta-blocker pre-surgery [87].

Vitamin C also regenerates $\alpha$-Tocopherol (vitamin E); therefore, a combination therapy might offer more benefits compared to a monotherapy [19]. A combination of vitamins $C$ and $E$ significantly reduced 28-day mortality and duration of mechanical ventilation in ICU patients, in a study by Crimi et al. [170]. Howe et al. observed a reduction of mechanical ventilation and a trend towards reduced all-cause mortality and ICU-LOS in critically ill patients [171]. In cardiac surgery patients, the combined vitamin $C$ and $E$ therapy lowered oxidative stress, as demonstrated by lower lipid oxidation and lysosomal enzyme activity [172], improved function of the pulmonary vessels [173] and seemed to have an anti-inflammatory effect, as measured in lower CRP levels in a study by Gunes et al. [174]; see also Table 3.

Table 3. RCTs investigating antioxidant cocktails in cardiac surgery.

\begin{tabular}{llll}
\hline \multicolumn{1}{c}{ Author and Year } & $N$ & \multicolumn{1}{c}{ Treatment } & \multicolumn{1}{c}{ Outcomes } \\
\hline Barta 1991 [172] & 20 & $\begin{array}{l}\text { Preop: 2000 IU Vit E: 12 h before surgery; 2 g vitamin C in the } \\
\text { morning on the day of surgery }\end{array}$ & $\begin{array}{l}\text { Inhibition of the decrease of catalase Lower lipid oxidation } \\
\text { and lysosomal enzymes in intervention group }\end{array}$ \\
\hline Westhuyzen 1997 [175] & 76 & Preoperative (7-10 days): 1 g vitamin C and 750 IU Vit E & $\begin{array}{l}\text { Supplementation of the vitamins prevented depletion, but } \\
\text { provided no clinical advantage }\end{array}$ \\
\hline Angdin 2003 [173] & 22 & $\begin{array}{l}\text { Preop: 900 mg Vit E for 10-14 days plus 1 } \times \text { 2 g vitamin C and } \\
\text { 600 mg allopurinol the evening before surgery, and } \\
\text { acetylcysteine during surgery }\end{array}$ & $\begin{array}{l}\text { Reduction of pulmonary vascular endothelial dysfunction in } \\
\text { the group treated with ntioxidants }\end{array}$ \\
\hline Castillo 2011 [176] & 95 & $\begin{array}{l}\text { Preop: for 7 days } n \text {-3 PUFA 2 g/day } \\
\text { Plus, for 2 days preop until discharge vitamin C 1 g/day and } \\
\text { Vit E 400 IU/day }\end{array}$ & Decrease in oxidative stress-related biomarkers in atrial tissue \\
\hline Gunes 2012 [174] & 59 & $\begin{array}{l}\text { Preop: vitamin C 500 mg and Vit E 300 mg Postop: vitamin C } \\
\text { 500 mg/day and Vit E 300 mg/day for 4 days }\end{array}$ & Significant reduction of CRP \\
\hline Rodrigo 2013 [177] & 203 & $\begin{array}{l}\text { Preop: 1 g/day vitamin C plus PUFA and Vit E for 2 days } \\
\text { preop until discharge }\end{array}$ & Decrease in oxidative stress-related biomarkers in atrial tissue \\
\hline Stanger 2014 [178] & 75 & $\begin{array}{l}\text { 4 subgroups: control, vitamins, } n \text {-3 PUFAs, and a combination } \\
\text { of vitamins and } n-3 \text { PUFAs } \\
\text { Vitamin group: 500 mg vitamin C + 45 IE Vit E 30 min before } \\
\text { reperfusion, postop and 120 min after reperfusion }\end{array}$ & $\begin{array}{l}\text { Attenuation of postop oxidative stress, Oxidative stress } \\
\text { associated with consumption of antioxidants and onset of AF }\end{array}$ \\
\hline Rezk 2017 [87] & $\begin{array}{l}\text { 3 days preoperatively } \\
\text { Group 1: } \beta \text {-blocker: } 5 \text { mg bisoprolol and 2 g/day vitamin C } \\
\text { Group 2: } \beta \text {-blocker only }\end{array}$ & $\begin{array}{l}\text { Significantly lower incidence in vitamin C group, ICU-LOS, } \\
\text { need for inotropes and mechanical ventilation }\end{array}$ \\
\hline
\end{tabular}

\section{Vit $\mathrm{E}=$ vitamin $\mathrm{E}$.}

\section{Practical Approach to Vitamin C Supplementation}

\subsection{Risks and Side Effects}

As demonstrated above, many studies have supplemented vitamin $C$, but significant adverse effects on patients in short term use have not yet been reported. This is true for low, as well as for dosages of $200 \mathrm{mg} / \mathrm{kg} /$ day and up to extremely high dosages of $1500 \mathrm{mg} / \mathrm{kg}$ three times a week in cancer patients [49]. Possible adverse effects are related to dosage, enteral route, and duration of vitamin C supplementation and include:

- Diarrhea and abdominal bloating [27]

- False negative tests for gastrointestinal occult bleeding [27]

- Aggravation of iron overload in patients with hemochromatosis or other diseases requiring frequent blood transfusions, such as thalassemia major and sideroblastic anemia [27]

- Possible adverse pro-oxidative effect in large dosages in case of iron overload [49]

- Possible hyperuricosuria [27] 
- Formation of kidney stones through precipitation of calcium oxalate, especially in patients with chronic renal failure, hyperoxaluria and recurring formation of kidney stones $[27,49]$

- Hemolysis in patients with hereditary glucose-6-phosphate dehydrogenase (G6DP) deficiency, when administered in high dosages of $>4 \mathrm{~g} /$ day [27]

- False-high measurements of blood glucose in hand-held devices $[179,180]$.

Importantly, vitamin C can act not only as antioxidant, but also as pro-oxidant in the presence of redox-active transition metal ions [181]. In theory, the reduction of metal ions (e.g., iron or copper) by vitamin $C$ in vitro can result in the formation of highly reactive hydroxyl radicals via reaction of the reduced metal ions with hydrogen peroxide, which is known as Fenton chemistry. Yet, this reaction requires the availability of free, redox-active metal ions and a low ratio of vitamin $C$ to metal ion, which is unlikely to occur in human biology under normal circumstances [181-183]. Vitamin C might act as prodrug to hydrogen peroxide even without metal chelators when administered in pharmacologic concentrations but led to no hydrogen peroxide accumulation in the blood vivo [184]. In this context, a few studies [185] have suggested a pro-oxidative effect of vitamin C, portrayed as an underlying reason for negative effects, although none of these ever confirmed a causative relation.

\subsection{Application Strategies}

\subsubsection{Dosing}

Current literature does not support a specific vitamin C dosing strategy in cardiac surgery, in the absence of a definitive trial. The dose typically administered by parenteral and enteral nutrition is $200 \mathrm{mg} /$ day, which is recommended for the healthy population. In a study by Carr et al., standard enteral or parenteral nutritional therapy with a mean of $125 \mathrm{mg}$ /day did not prevent hypovitaminosis $C$ in critically ill patients [46]. Even after less invasive and elective surgery, such as maxilla-facial surgery, higher dosages (500-2000 mg/day, mean $1150 \mathrm{mg}$ /day) were required to increase plasma vitamin C levels and compensate for the observed loss $[47,186,187]$. In patients experiencing significant inflammation and oxidative stress, such as trauma, burn, sepsis and cardiac surgery patients, the vitamin $C$ requirement seems to increase dramatically. A dosage of 3-4 g/day parenterally seems necessary to normalize the vitamin C plasma levels in patients with burns or sepsis [49] or critically ill trauma patients [48]. Probable causes for this high demand are higher consumption due to the antioxidant capacity of vitamin $C$, as well as increased renal clearance during vitamin $C$ substitution.

Fowler et al. recently published a phase 1 clinical trial, suggesting that $200 \mathrm{mg} / \mathrm{kg} /$ day yields higher plasma levels of vitamin C and more favorable Sequential Organ Failure Assessment (SOFA) scores compared to $50 \mathrm{mg} / \mathrm{kg} /$ day in severely septic patients [51]. A very high dosage of $66 \mathrm{mg} / \mathrm{kg} / \mathrm{h}$ for the first $24 \mathrm{~h}$ was used in the study by Tanaka et al. in burn patients, which led to reduced fluid demand and increased urine production $[54,55]$.

In cardiac surgery patients, the dosing regimen used in the previously mentioned studies are extremely heterogenous. Most studies use a single dose of $2 \mathrm{~g}$ once prior to surgery. Postoperatively, a very small dosage of less than $1 \mathrm{~g} /$ day was administered in many studies $[141,157,159,162,163,165,167]$. However, single-dosages as high as $150 \mathrm{mg} / \mathrm{kg}$ [86] or $250 \mathrm{mg} / \mathrm{kg}$ have also been applied [158]. To our knowledge, there is no dose-finding study on cardiac surgery patients yet.

\subsubsection{Timing}

Oxidative damage is highest minutes after reperfusion; hence, early administration may be optimal. Logically, preoperative administration might refuel the body's antioxidant capabilities, preparing for $\mathrm{CPB}$. Application of a dosage before the removal of the aortic cross-clamp and reperfusion might achieve the minimal ROS-scavenging plasma-levels of 1-10 mmol/L [49].

In one study, the cardiac index was significantly higher in the first $6 \mathrm{~h}$ after the operation in patients receiving a mega-dose of $125 \mathrm{mg} / \mathrm{kg}$, suggesting that the effect of vitamin C might wear off after that period of time [86]. Ruemelin et al. showed a rapid decrease in plasma concentration after 
the end of the infusion [187]. In a study by Tanaka [55], serum levels of vitamin C increased quickly under continuous infusion, remained elevated until $12 \mathrm{~h}$ after infusion and decreased rapidly.

To our knowledge, no trial studied the duration of vitamin $C$ administration in cardiac surgery patients, or even in other critically ill patients. In cardiac surgery, the greatest trauma is related to the surgery itself, as well as to ischemia/reperfusion after cardiopulmonary bypass. The most relevant oxidative stress and inflammation is expected within the first hoursand days after surgery. Bjugstadt et al. demonstrated that oxidative stress remained significant, even days after injury, while the extent of oxidative stress on the fourth day after trauma was the most relevant for patients' outcomes $[188,189]$. Therefore, the most reasonable duration for substitution might be $96 \mathrm{~h}$ and is also used by Fowler et al. ([51] and NCT02106975).

\subsubsection{Mode of Administration}

The route of vitamin $C$ administration may be of pivotal importance, but studies comparing the oral versus intravenous application in patients are still missing.

Studies showed that serum vitamin C cannot be raised to physiological levels after surgery, if administered orally, even if the highest tolerated dosage is administered enterally Intravenous application of vitamin $C$ results in much higher circulating ascorbate concentrations [46], while the effects of these supra-physiological vitamin $C$ concentrations have yet to be studied. On the other hand, even an oral application of vitamin C was shown to be beneficial in RCTs by Sadeghpour [141], and Dehghani [165].

Positive effects of high doses of vitamin C (if administered either orally or by infusion) on arterial vasodilation have been reported (review in detail in [28]). Although comprehensive studies, evaluating carefully the potential differences between oral and intravenous vitamin C, are missing, it is suggested that intravenous application provides advantages due to higher bioavailability and faster action time in the vascular system. When vitamin $C$ is supplemented parenterally, supraphysiological dosages can safely be administered and the antioxidant effects of vitamin C may be increased [49].

Another issue is the application strategy of the vitamin. One possibility to counteract rapid metabolic clearance and drop of plasma vitamin $C$ levels would be continuous infusion, which is feasible and effective under UV-protection [55]. However, vitamin C's lability allows for degradation of the vitamin before it enters the patient. Another option might be frequent bolus dosing, as used in a trial by Fowler et al. [51].

\subsubsection{Monitoring}

As outlined before, vitamin C can be measured in its oxidized form DHA. When monitoring DHA in blood samples, it has to be kept in mind that ascorbic acid is sensitive to oxidation and degradation during blood sampling, handling, storage and analysis. Therefore, the handling, storage and following shipment to reference laboratories may be problematic [190]. Factors influencing the stability of DHA in whole blood and serum are temperature, light-exposure, $\mathrm{pH}$, contamination with copper or iron and anticoagulant of the blood sample [26,191], as well as dissolved oxygen, solvent, ionic strength, trace metals and oxidizing enzymes. In a refrigerator at $4{ }^{\circ} \mathrm{C}$, the degradation of vitamin $\mathrm{C}$ within $24 \mathrm{~h}$ is $1.8 \%$ in serum tubes and $7.2 \%$ in plasma tubes [192].

Therefore, blood samples should be drawn immediately, stored in crushed ice in a light protected box, and be delivered within $2 \mathrm{~h}$ for reliable vitamin $\mathrm{C}$ measurements [193]. When whole blood is immediately centrifuged, acidified and stored at $-70{ }^{\circ} \mathrm{C}$, ascorbic acid degrades very slowly and can be analyzed for at least 6 years. However, due to different degradation rates depending on the acid and anticoagulant used in sampling tubes, a quick analysis seems preferable [26,194]. High performance liquid chromatography (HPLC) with electrochemical detection is the current gold standard of vitamin C measurement, which usually requires the stabilization of vitamin C through acid or alcohol precipitation, usually combined with a metal chelator [191]. Robitaille and Hoffer showed that the simpler UV light detection is equivalent to electrochemical detection [190]. A recent 
study by Pullar et al. demonstrated a good stability of DHA for up to a year at $-80{ }^{\circ} \mathrm{C}$, both as plasma, as well as in extracts with perchloric acid (PCA) containing $100 \mu \mathrm{mol} / 1$ of the metal chelator diethylenetriaminepentaacetic acid (DTPA) extracts, with a loss of $8 \%$ in 12 months [191].

Considering these influencing factors, the measurement of vitamin $\mathrm{C}$ is elaborate and costly and therefore, not readily accessible in the ICU.

\section{Discussion and Future Directions}

The ways in which vitamin $C$ attenuates inflammation and oxidative damage and its clinical application is a current topic of interest. Preclinical as well as preliminary clinical studies have demonstrated the beneficial effects of vitamin $C$ on organ function during inflammation and oxidative stress.

No serious adverse events have been reported in any of the cited studies, highlighting the safety of this pharmaco-nutrient. However, despite the outlined promising effects, only a few adequately designed clinical trials have been conducted to provide robust evidence about vitamin C's influence on organ dysfunction. One cause might be the variance of the supplementation strategy (dose and timing) used in the existing studies. Besides, the overall importance of existing RCTs is weakened by the heterogeneity in outcome measuring and reporting, which hinders comparison of interventions. This problem is encountered by so-called core outcome sets. These core outcome sets include minimal outcome parameters, which should be measured and reported in clinical trials of a specific area. Their use ameliorates the comparison of trials' results and their combination, if appropriate [195]. In the future, a specific core outcome set should be developed for trials investigating the effect of (pharmaco-)nutrition in cardiac surgery. Larger and adequately designed clinical studies are urgently needed, before any recommendation regarding the application of vitamin $C$ in cardiac surgery can be made.

Any conclusive evidence of the benefits of vitamin $C$ in cardiac surgery patients would lead to rapid implementation of this promising therapy for four reasons: (1) The overall safety profile of vitamin C may enable a broad use; (2) the feasibility of vitamin C administration without any dose adjustments; (3) familiarity for clinicians and patients as a therapy for cancer and in some burn units; (4) low costs to produce and administer.

Author Contributions: A.H., and C.S. equally contributed to the conception and design of the research together with D.K.H., P.M. and C.B. A.H. and S.W. drafted the manuscript together with C.B., C.N. and C.S. Graphics were provided by A.H. A.H., S.W., C.B., C.N., P.L., D.K.H. and C.S., contributed to the acquisition of data. N.K.J.A., D.K.H., and C.B. contributed to the study selection. All authors contributed to analysis and interpretation of the reviewed data, critically revised the manuscript, agreed to be fully accountable for ensuring the integrity and accuracy of the work, and read and approved the final manuscript.

Funding: No funding was received for this review.

Conflicts of Interest: The authors declare no conflict of interest that may be perceived as inappropriately influencing the representation or interpretation of reported research results.

\section{Abbreviations}

$\begin{array}{ll}\text { AF } & \text { Atrial Fibrillation } \\ \text { AKI } & \text { Acute Kidney Injury } \\ \text { CABG } & \text { Coronary Artery Bypass Graft } \\ \text { CPB } & \text { Cardiopulmonary Bypass } \\ \text { CRP } & \text { C-reactive Protein } \\ \text { DHA } & \text { Dehydroascorbate } \\ \text { GI } & \text { Gastrointestinal } \\ \text { ICU } & \text { Intensive Care Unit } \\ \text { iNOS } & \text { Inducible Nitric Oxide Synthetase } \\ \text { I/R } & \text { Ischemia/Reperfusion } \\ \text { i.v. } & \text { Intravenous } \\ \text { LOS } & \text { Length of Stay } \\ \text { N.A. } & \text { Not Available } \\ \text { NFKB } & \text { Nuclear Factor kappa-light-chain enhancer of activated B cells }\end{array}$




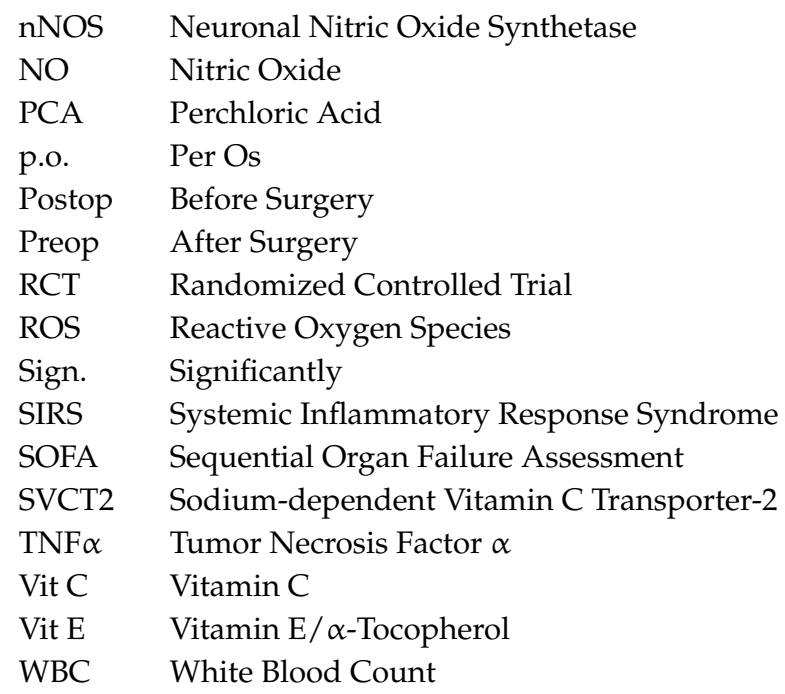

\section{References}

1. Prondzinsky, R.; Knüpfer, A.; Loppnow, H.; Redling, F.; Lehmann, D.W.; Stabenow, I.; Witthaut, R.; Unverzagt, S.; Radke, J.; Zerkowski, H.R.; et al. Surgical trauma affects the proinflammatory status after cardiac surgery to a higher degree than cardiopulmonary bypass. J. Thorac. Cardiovasc. Surg. 2005, 129, 760-766. [CrossRef] [PubMed]

2. Laffey, J.G.; Boylan, J.F.; Cheng, D.C.H. The systemic inflammatory response to cardiac surgery: Implications for the anesthesiologist. Anesthesiology 2002, 97, 215-252. [PubMed]

3. Bronicki, R.A.; Hall, M. Cardiopulmonary bypass-induced inflammatory response: Pathophysiology and treatment. Pediatric critical care medicine: A journal of the Society of Critical Care Medicine and the World. Pediatr. Crit. Care Med. 2016, 17, S272-S278. [CrossRef] [PubMed]

4. Butler, J.; Rocker, G.M.; Westaby, S. Inflammatory Response to Cardiopulmonary Bypass. Ann. Thorac. Surg. 1993, 55, 552-559. [CrossRef]

5. Chenoweth, D.E.; Cooper, S.W.; Hugli, T.E.; Stewart, R.W.; Blackstone, E.H.; Kirklin, J.W. Complement activation during cardiopulmonary bypass: Evidence for generation of c3a and c5a anaphylatoxins. N. Eng. J. Med. 1981, 304, 497-503. [CrossRef] [PubMed]

6. Hall, T.S. The pathophysiology of cardiopulmonary bypass: The risks and benefits of hemodilution. Chest 1995, 107, 1125-1133. [CrossRef] [PubMed]

7. Khabar, K.S.; ElBarbary, M.A.; Khouqeer, F.; Devol, E.; Al-Gain, S.; Al-Halees, Z. Circulating Endotoxin and Cytokines After Cardiopulmonary Bypass: Differential Correlation with Duration of Bypass and Systemic Inflammatory Response/multiple Organ Dysfunction Syndromes. Clin. Immunol. Immunopathol. 1997, 85, 97-103. [CrossRef] [PubMed]

8. Moore, F.D.; Warner, K.G.; Assousa, S.; Valeri, C.R.; Khuri, S.F. The effects of complement activation during cardiopulmonary bypass. Attenuation by hypothermia, heparin, and hemodilution. Ann. Surg. 1998, 208, 95-103. [CrossRef]

9. Raja, S.G.; Berg, G.A. Impact of off-pump coronary artery bypass surgery on systemic inflammation: Current best available evidence. J. Card. Surg. 2007, 22, 445-455. [CrossRef] [PubMed]

10. Hall, R. Identification of inflammatory mediators and their modulation by strategies for the management of the systemic inflammatory response during cardiac surgery. J. Cardiothorac. Vasc. Anesth. 2013, 27, 983-1033. [CrossRef] [PubMed]

11. Landis, R.C.; Brown, J.R.; Fitzgerald, D.; Likosky, D.S.; Shore-Lesserson, L.; Baker, R.A.; Hammon, J.W. Attenuating the systemic inflammatory response to adult cardiopulmonary bypass: A critical review of the evidence base. J. Extra Corpor. Technol. 2014, 46, 197-211. [PubMed]

12. Rossaint, J.; Berger, C.; Aken, H.V.; Scheld, H.H.; Zahn, P.K.; Rukosujew, A.; Zarbock, A. Cardiopulmonary bypass during cardiac surgery modulates systemic inflammation by affecting different steps of the leukocyte recruitment cascade. PLOS ONE 2012, 7, e45738. [CrossRef] [PubMed] 
13. Paparella, D.; Yau, T.M.; Young, E. Cardiopulmonary bypass induced inflammation: Pathophysiology and treatment. an update. Eur. J. Cardiothorac. Surg. 2002, 21, 232-244. [CrossRef]

14. Hickey, E.; Karamlou, T.; You, J.; Ungerleider, R.M. Effects of Circuit Miniaturization in Reducing Inflammatory Response to Infant Cardiopulmonary Bypass by Elimination of Allogeneic Blood Products. Ann. Thorac. Surg. 2006, 81, S2367-S2372. [CrossRef] [PubMed]

15. Jansen, P.G.; te Velthuis, H.; Bulder, E.R.; Paulus, R.; Scheltinga, M.R.; Eijsman, L.; Wildevuur, C.R. Reduction in prime volume attenuates the hyperdynamic response after cardiopulmonary bypass. Ann. Thorac. Surg. 1995, 60, 544-549. [CrossRef]

16. Magder, S. Reactive oxygen species: Toxic molecules or spark of life? Crit. Care 2006, 10, 208. [CrossRef] [PubMed]

17. Roy, J.; Galano, J.-M.; Durand, T.; Le Guennec, J.Y.; Lee, J.C.-Y. Physiological role of reactive oxygen species as promoters of natural defenses. FASEB J. 2017, 31, 3729-3745. [CrossRef] [PubMed]

18. Roth, E.; Manhart, N.; Wessner, B. Assessing the antioxidative status in critically ill patients. Curr. Opin. Clin. Nutr. Metab. Care 2004, 7, 161-168. [CrossRef] [PubMed]

19. Koekkoek, W.A.; van Zanten, A.R. Antioxidant vitamins and trace elements in critical illness. Nutr. Clin. Pract. 2016, 31, 457-474. [CrossRef] [PubMed]

20. Levy, J.H.; Tanaka, K.A. Inflammatory Response to Cardiopulmonary Bypass. Ann. Thorac. Surg. 2003, 75, S715-S720. [CrossRef]

21. Seghaye, M.C.; Grabitz, R.G.; Duchateau, J.; Busse, S.; Däbritz, S.; Koch, D.; Alzen, G.; Hörnchen, H.; Messmer, B.J.; Von Bernuth, G. Inflammatory reaction and capillary leak syndrome related to cardiopulmonary bypass in neonates undergoing cardiac operations. J. Thorac. Cardiovasc. Surg. 1996, 112, 687-697. [CrossRef]

22. Crimi, E.; Sica, V.; Slutsky, A.S.; Zhang, H.; Williams-Ignarro, S.; Ignarro, L.J.; Napoli, C. Role of oxidative stress in experimental sepsis and multisystem organ dysfunction. Free Radic. Res. 2006, 40, 665-672. [CrossRef] [PubMed]

23. Kollef, M.H.; Wragge, T.; Pasque, C. Determinants of mortality and multiorgan dysfunction in cardiac surgery patients requiring prolonged mechanical ventilation. Chest 1995, 107, 1395-1401. [CrossRef] [PubMed]

24. Suleiman, M.-S.; Zacharowski, K.; Angelini, G.D. Inflammatory response and cardioprotection during open-heart surgery: The importance of anaesthetics. Br. J. Pharmacol. 2008, 153, 21-33. [CrossRef] [PubMed]

25. Stoppe, C.; McDonald, B.; Benstoem, C.; Elke, G.; Meybohm, P.; Whitlock, R.; Fremes, S.; Fowler, R.; Lamarche, R.; Jiang, X.; et al. Evaluation of persistent organ dysfunction plus death as a novel composite outcome in cardiac surgical patients. J. Cardiothorac. Vasc. Anesth. 2016, 30, 30-38. [CrossRef] [PubMed]

26. Karlsen, A.; Blomhoff, R.; Gundersen, T.E. Stability of whole blood and plasma ascorbic acid. Eur. J. Clin. Nutr. 2007, 61, 1233-1236. [CrossRef] [PubMed]

27. Levine, M.; Rumsey, S.C.; Daruwala, R.; Park, J.B.; Wang, Y. Criteria and recommendations for vitamin C intake. JAMA 1999, 281, 1415-1423. [CrossRef] [PubMed]

28. Carr, A.C.; Frei, B. Toward a new recommended dietary allowance for vitamin $\mathrm{C}$ based on antioxidant and health effects in humans. Am. J. Clin. Nutr. 1999, 69, 1086-1107. [CrossRef] [PubMed]

29. Jacob, R.A.; Burri, B.J. Human metabolism and the requirement for vitamin C. In Vitamin C in Health and Disease; Packer, L., Fuchs, J., Eds.; Marcel Dekker Inc.: New York, NY, USA, 1997; pp. 341-366.

30. Tsao, C.S. An overview of ascorbic acid chemistry and biochemistry. In Vitamin C in Health and Disease; Packer, L., Fuchs, J., Eds.; Marcel Dekker Inc.: New York, NY, USA, 1997; pp. 25-58.

31. Huang, Y.; Tang, X.; Xie, W.; Zhou, Y.; Li, D.; Zhou, Y.; Zhu, J.; Yuan, T.; Lai, L.; Pang, D.; Ouyang, H. Vitamin $C$ enhances in vitro and in vivo development of porcine somatic cell nuclear transfer embryos. Biochem. Biophys. Res. Commun. 2011, 411, 397-401. [CrossRef] [PubMed]

32. Esteban, M.A.; Wang, T.; Qin, B.; Yang, J.; Qin, D.; Cai, J.; Li, W.; Weng, Z.; Chen, J.; Ni, S.; et al. Vitamin C enhances the generation of mouse and human induced pluripotent stem cells. Cell Stem. Cell 2010, 6, 71-79. [CrossRef] [PubMed]

33. Takahashi, T.; Lord, B.; Schulze, P.C.; Fryer, R.M.; Sarang, S.S.; Gullans, S.R.; Lee, R.T. Ascorbic acid enhances differentiation of embryonic stem cells into cardiac myocytes. Circulation 2003, 107, 1912-1916. [CrossRef] [PubMed] 
34. Cao, N.; Liu, Z.; Chen, Z.; Wang, J.; Chen, T.; Zhao, S.; Ma, Y.; Qin, L.; Kang, J.; Wei, B.; et al. Ascorbic acid enhances the cardiac differentiation of induced pluripotent stem cells through promoting the proliferation of cardiac progenitor cells. Cell Res. 2012, 22, 219-236. [CrossRef] [PubMed]

35. Yin, R.; Mao, S.-Q.; Zhao, B.; Chong, Z.; Yang, Y.; Zhao, C.; Zhang, D.; Huang, H.; Gao, J.; Li, Z.; et al. Ascorbic acid enhances tet-mediated 5-methylcytosine oxidation and promotes DNA demethylation in mammals. J. Am. Chem. Soc. 2013, 135, 10396-10403. [CrossRef] [PubMed]

36. Frei, B.; England, L.; Ames, B.N. Ascorbate is an outstanding antioxidant in human blood plasma. Proc. Natl. Acad. Sci. USA 1989, 86, 6377-6381. [CrossRef] [PubMed]

37. Frei, B.; Stocker, R.; England, L.; Ames, B.N. Ascorbate: The most effective antioxidant in human blood plasma. Antioxid. Ther. Prev. Med. 1990, 264, 155-163.

38. Carr, A.C.; Maggini, S. Vitamin C and immune function. Nutrients 2017, 9, 1211. [CrossRef] [PubMed]

39. Carr, A.C.; Shaw, G.M.; Fowler, A.A.; Natarajan, R. Ascorbate-dependent vasopressor synthesis: A rationale for vitamin C administration in severe sepsis and septic shock? Crit. Care 2015, 19, 418. [CrossRef] [PubMed]

40. Oudemans-van Straaten, H.M.; Spoelstra-de Man, A.M.; de Waard, M.C. Vitamin C revisited. Crit. Care 2014, 18, 460. [CrossRef] [PubMed]

41. Berger, M.M.; Oudemans-van Straaten, H.M. Vitamin C supplementation in the critically ill patient. Curr. Opin. Clin. Nutr. Metabol. Care 2015, 18, 193-201. [CrossRef] [PubMed]

42. Han, M.; Pendem, S.; Teh, S.L.; Sukumaran, D.K.; Wu, F.; Wilson, J.X. Ascorbate protects endothelial barrier function during septic insult: Role of protein phosphatase type 2a. Free Radic. Biol. Med. 2010, 48, 128-135. [CrossRef] [PubMed]

43. Tyml, K. Vitamin C and microvascular dysfunction in systemic inflammation. Antioxidants 2017, 6, 49. [CrossRef] [PubMed]

44. Yamamoto, T.; Kinoshita, M.; Shinomiya, N.; Hiroi, S.; Sugasawa, H.; Matsushita, Y.; Majima, T.; Saitoh, D.; Seki, S. Pretreatment with ascorbic acid prevents lethal gastrointestinal syndrome in mice receiving a massive amount of radiation. J. Radiat. Res. 2010, 51, 145-156. [CrossRef] [PubMed]

45. Cecconi, M.; Evans, L.; Levy, M.; Rhodes, A. Sepsis and septic shock. Lancet 2018, 392, 75-87. [CrossRef]

46. Carr, A.C.; Rosengrave, P.C.; Bayer, S.; Chambers, S.; Mehrtens, J.; Shaw, G.M. Hypovitaminosis C and vitamin $\mathrm{C}$ deficiency in critically ill patients despite recommended enteral and parenteral intakes. Crit. Care 2017, 21, 300. [CrossRef] [PubMed]

47. Wilson, J.X. Evaluation of vitamin C for adjuvant sepsis therapy. Antioxid. Redox Signal. 2013, 19, $2129-2140$. [CrossRef] [PubMed]

48. Long, C.L.; Maull, K.I.; Krishnan, R.S.; Laws, H.L.; Geiger, J.W.; Borghesi, L.; Franks, W.; Lawson, T.C.; Sauberlich, H.E. Ascorbic acid dynamics in the seriously ill and injured. J. Surg. Res. 2003, 109, 144-148. [CrossRef]

49. Angelique, M.E.; Spoelstra-de Man, A.M.; Elbers, P.W.; Oudemans-van Straaten, H.M. Making sense of early high-dose intravenous vitamin $C$ in ischemia/reperfusion injury. Crit. Crit. Care 2018, 22, 70.

50. Borrelli, E.; Roux-Lombard, P.; Grau, G.E.; Girardin, E.; Ricou, B.; Dayer, J.M.; Suter, P.M. Plasma concentrations of cytokines, their soluble receptors, and antioxidant vitamins can predict the development of multiple organ failure in patients at risk. Crit. Care Med. 1996, 24, 392-397. [CrossRef] [PubMed]

51. Fowler, A.A.; Syed, A.A.; Knowlson, S.; Sculthorpe, R.; Farthing, D.; De Wilde, C.; Farthing, C.A.; Larus, T.L.; Martin, E.; Brophy, D.F.; et al. Phase I safety trial of intravenous ascorbic acid in patients with severe sepsis. J. Transl. Med. 2014, 12, 32. [CrossRef] [PubMed]

52. Zabet, M.H.; Mohammadi, M.; Ramezani, M.; Khalili, H. Effect of high-dose ascorbic acid on vasopressor's requirement in septic shock. J. Res. Pharm. Pract. 2016, 5, 94-100. [PubMed]

53. Nathens, A.B.; Neff, M.J.; Jurkovich, G.J.; Klotz, P.; Farver, K.; Ruzinski, J.T.; Radella, F.; Garcia, I.; Maier, R.V. Randomized, prospective trial of antioxidant supplementation in critically ill surgical patients. Ann. Surg. 2002, 236, 814-822. [CrossRef] [PubMed]

54. Kahn, S.A.; Beers, R.J.; Lentz, C.W. Resuscitation after severe burn injury using high-dose ascorbic acid: A retrospective review. J. Burn. Care Res. 2011, 32, 110-117. [CrossRef] [PubMed]

55. Tanaka, H.; Matsuda, T.; Miyagantani, Y.; Yukioka, T.; Matsuda, H.; Shimazaki, S. Reduction of resuscitation fluid volumes in severely burned patients using ascorbic acid administration: A randomized, prospective study. Arch. Surg. 2000, 135, 326-331. [CrossRef] [PubMed] 
56. Bouras, E.; Chourdakis, M.; Grammatikopoulou, M.G.; Heyland, D.K. Nutrition therapy practices applied on severe burn patients: Results from the ins 2014 survey. Clin. Nutr. ESPEN 2018, 24, 182. [CrossRef] [PubMed]

57. Ahmad, A.; Shah, S.A.; Badshah, H.; Kim, M.J.; Ali, T.; Yoon, G.H.; Kim, T.H.; Abid, N.B.; Rehman, S.U.; Khan, S.; et al. Neuroprotection by Vitamin C Against Ethanol-Induced Neuroinflammation Associated Neurodegeneration in the Developing Rat Brain. CNS Neurol. Disord. Drug Targets 2016, 15, 360-370. [CrossRef] [PubMed]

58. Huang, J.; Agus, D.B.; Winfree, C.J.; Kiss, S.; Mack, W.J.; McTaggart, R.A.; Choudhri, T.F.; Kim, L.J.; Mocco, J.; Pinsky, D.J.; et al. Dehydroascorbic acid, a blood-brain barrier transportable form of vitamin C, mediates potent cerebroprotection in experimental stroke. Proc. Natl. Acad. Sci. USA 2001, 98, 11720-11724. [CrossRef] [PubMed]

59. Hu, X.; Yuan, L.; Wang, H.; Li, C.; Cai, J.; Hu, Y.; Ma, C. Efficacy and safety of vitamin C for atrial fibrillation after cardiac surgery: A meta-analysis with trial sequential analysis of randomized controlled trials. Int. J. Surg. 2017, 37, 58-64. [CrossRef] [PubMed]

60. Polymeropoulos, E.; Bagos, P.; Papadimitriou, M.; Rizos, I.; Patsouris, E.; Toumpoulis, I. Vitamin C for the Prevention of Postoperative Atrial Fibrillation after Cardiac Surgery: A Meta-Analysis. Adv. Pharm. Bull. 2016, 6, 243-250. [CrossRef] [PubMed]

61. May, J.M.; Harrison, F.E. Role of vitamin C in the function of the vascular endothelium. Antioxid. Redox Signal. 2013, 19, 2068-2083. [CrossRef] [PubMed]

62. Ashor, A.W.; Lara, J.; Mathers, J.C.; Siervo, M. Effect of vitamin C on endothelial function in health and disease: A systematic review and meta-analysis of randomised controlled trials. Atherosclerosis 2014, 235, 9-20. [CrossRef] [PubMed]

63. Geng, J.; Qian, J.; Si, W.; Cheng, H.; Ji, F.; Shen, Z. The clinical benefits of perioperative antioxidant vitamin therapy in patients undergoing cardiac surgery: A meta-analysis. Interact. Cardiovasc. Thorac. Surg. 2017, 5 , 966-974. [CrossRef] [PubMed]

64. Al-Asmari, A.M.; Khan, A.Q.; Al-Qasim, A.M.; Al-Yousef, Y. Ascorbic acid attenuates antineoplastic drug 5 -fluorouracil induced gastrointestinal toxicity in rats by modulating the expression of inflammatory mediators. Toxicol. Rep. 2015, 2, 908-916. [CrossRef] [PubMed]

65. Eagle, K.A.; Guyton, R.A.; Davidoff, R.; Edwards, F.H.; Ewy, G.A.; Gardner, T.J.; Hart, J.C.; Herrmann, H.C.; Hillis, L.D.; Hutter, A.M., Jr.; et al. ACC/AHA 2004 guideline update for coronary artery bypass graft surgery: A report of the American College of Cardiology/American Heart Association Task Force on Practice Guidelines (Committee to Update the 1999 Guidelines for Coronary Artery Bypass Graft Surgery). Circulation 2004, 110, e340-e437. [PubMed]

66. Biancari, F.; Tauriainen, T.; Perrotti, A.; Dalén, M.; Faggian, G.; Franzese, I.; Chocron, S.; Ruggieri, V.G.; Bounader, K.; Gulbins, H.; et al. Bleeding, transfusion and the risk of stroke after coronary surgery: A prospective cohort study of 2357 patients. Int. J. Surg. 2016, 32, 50-57. [CrossRef] [PubMed]

67. Cropsey, C.; Kennedy, J.; Han, J.; Pandharipande, P. Cognitive dysfunction, delirium, and stroke in cardiac surgery patients. Semin. Cardiothorac. Vasc. Anesth. 2015, 19, 309-317. [CrossRef] [PubMed]

68. Knipp, S.C.; Weimar, C.; Schlamann, M.; Schweter, S.; Wendt, D.; Thielmann, M.; Benedik, J.; Jakob, H. Early and long-term cognitive outcome after conventional cardiac valve surgery. Interact. Cardiovasc. Thorac. Surg. 2017, 24, 534-540. [CrossRef] [PubMed]

69. Selnes, O.A.; Gottesman, R.F.; Grega, M.A.; Baumgartner, W.A.; Zeger, S.L.; McKhann, G.M. Cognitive and neurologic outcomes after coronary-artery bypass surgery. N. Engl. J. Med. 2012, 366, 250-257. [CrossRef] [PubMed]

70. Van Harten, A.E.; Scheeren, T.W.; Absalom, A.R. A review of postoperative cognitive dysfunction and neuroinflammation associated with cardiac surgery and anaesthesia. Anaesthesia 2012, 67, 280-293. [CrossRef] [PubMed]

71. Mangusan, R.F.; Hooper, V.; Denslow, S.A.; Travis, L. Outcomes associated with postoperative delirium after cardiac surgery. Am. J. Crit. Care 2015, 24, 156-163. [CrossRef] [PubMed]

72. Gess, B.; Lohmann, C.; Halfter, H.; Young, P. Sodium-dependent vitamin C transporter 2 (SVCT2) is necessary for the uptake of L-ascorbic acid into Schwann cells. Glia 2010, 58, 287-299. [CrossRef] [PubMed]

73. Harrison, F.E.; May, J.M. Vitamin C function in the brain: Vital role of the ascorbate transporter SVCT2. Free Radic. Biol. Med. 2009, 46, 719-730. [CrossRef] [PubMed] 
74. Eldridge, C.F.; Bunge, M.B.; Bunge, R.P.; Wood, P.M. Differentiation of axon-related schwann cells in vitro. I. ascorbic acid regulates basal lamina assembly and myelin formation. J. Cell Biol. 1987, 105, 1023-1034. [CrossRef] [PubMed]

75. Henry, P.T.; Chandy, M.J. Effect of ascorbic acid on infarct size in experimental focal cerebral ischaemia and reperfusion in a primate model. Acta Neurochir. 1998, 140, 977-980. [CrossRef] [PubMed]

76. Lagowska-Lenard, M.; Stelmasiak, Z.; Bartosik-Psujek, H. Influence of vitamin C on markers of oxidative stress in the earliest period of ischemic stroke. Pharmacol. Rep. 2010, 62, 751-756. [CrossRef]

77. Bonnefont-Rousselot, D.; Mahmoudi, A.; Mougenot, N.; Varoquaux, O.; Le Nahour, G.; Fouret, P.; Lechat, P. Catecholamine effects on cardiac remodelling, oxidative stress and fibrosis in experimental heart failure. Redox Rep. 2002, 7, 145-151. [CrossRef] [PubMed]

78. Ellenberger, C.; Sologashvili, T.; Cikirikcioglu, M.; Verdon, G.; Diaper, J.; Cassina, T.; Licker, M. Risk factors of postcardiotomy ventricular dysfunction in moderate-to-high risk patients undergoing open-heart surgery. Ann. Card. Anaesth. 2017, 20, 287-296. [PubMed]

79. Lomivorotov, V.V.; Efremov, S.M.; Kirov, M.Y.; Fominskiy, E.V.; Karaskov, A.M. Low-cardiac-output syndrome after cardiac surgery. J. Cardiothorac. Vasc. Anesth. 2017, 31, 291-308. [CrossRef] [PubMed]

80. Ding, W.; Ji, Q.; Shi, Y.; Ma, R. Predictors of low cardiac output syndrome after isolated coronary artery bypass grafting. Int. Heart J. 2015, 56, 144-149. [CrossRef] [PubMed]

81. Epting, C.L.; McBride, M.E.; Wald, E.L.; Costello, J.M. Pathophysiology of post-operative low cardiac output syndrome. Curr. Vasc. Pharmacol. 2016, 14, 14-23. [CrossRef] [PubMed]

82. Peretto, G.; Durante, A.; Limite, L.R.; Cianflone, D. Postoperative arrhythmias after cardiac surgery: Incidence, risk factors, and therapeutic management. Cardiol. Res. Pract. 2014, 2014, 615987. [CrossRef] [PubMed]

83. Saran, V.; Sharma, V.; Wambolt, R.; Yuen, V.G.; Allard, M.; McNeill, J.H. Combined metoprolol and ascorbic acid treatment prevents intrinsic damage to the heart during diabetic cardiomyopathy. Can. J. Physiol. Pharmacol. 2014, 92, 827-837. [CrossRef] [PubMed]

84. Hsu, C.C.; Wang, J.J. L-ascorbic acid and alpha-tocopherol attenuates liver ischemia-reperfusion induced of cardiac function impairment. Transplant. Proc. 2012, 44, 933-936. [CrossRef] [PubMed]

85. Kremer, T.; Harenberg, P.; Hernekamp, F.; Riedel, K.; Gebhardt, M.M.; Germann, G.; Heitmann, C.; Walther, A. High-dose vitamin $\mathrm{C}$ treatment reduces capillary leakage after burn plasma transfer in rats. J. Burn Care Res. 2010, 31, 470-479. [CrossRef] [PubMed]

86. Dingchao, H.; Zhiduan, Q.; Liye, H.; Xiaodong, F. The protective effects of high-dose ascorbic acid on myocardium against reperfusion injury during and after cardiopulmonary bypass. Thorac. Cardiovasc. Surg. 1994, 42, 276-278. [CrossRef] [PubMed]

87. Rezk, M.E. Role of ascorbic acid in reduction of the incidence of the atrial fibrillation in patients under b-blocker and undergoing coronary artery bypass graft operation in early post-operative period. J. Egypt. Soc. Cardio Thorac. Surg. 2017, 25, 198-203.

88. Ali-Hassan-Sayegh, S.; Mirhosseini, S.J.; Rezaeisadrabadi, M.; Dehghan, H.R.; Sedaghat-Hamedani, F.; Kayvanpour, E.; Popov, A.F.; Liakopoulos, O.J. Liakopoulos. Antioxidant supplementations for prevention of atrial fibrillation after cardiac surgery: An updated comprehensive systematic review and meta-analysis of 23 randomized controlled trials. Interact. Cardiovasc. Thorac. Surg. 2014, 18, 646-654. [CrossRef] [PubMed]

89. Baker, W.L.; Coleman, C.I. Meta-analysis of ascorbic acid for prevention of postoperative atrial fibrillation after cardiac surgery. Am. J. Health Syst. Pharm. 2016, 73, 2056-2066. [CrossRef] [PubMed]

90. Shi, R.; Li, Z.H.; Chen, D.; Wu, Q.C.; Zhou, X.L.; Tie, H.T. Sole and combined vitamin C supplementation can prevent postoperative atrial fibrillation after cardiac surgery: A systematic review and meta-analysis of randomized controlled trials. Clin. Cardiol. 2018, 41, 871-878. [CrossRef] [PubMed]

91. Hemilä, H.; Suonsyrjae, T. Vitamin C for preventing atrial fibrillation in high risk patients: A systematic review and meta-analysis. BMC Cardiovasc. Dis. 2017. [CrossRef] [PubMed]

92. Hemilä, H. Publication bias in meta-analysis of ascorbic acid for postoperative atrial fibrillation. Am. J. Health Syst. Pharm. 2017, 74, 372-373. [CrossRef] [PubMed]

93. García-Delgado, M.; Navarrete-Sánchez, I.; Colmenero, M. Preventing and managing perioperative pulmonary complications following cardiac surgery. Curr. Opin. Anaesthesiol. 2014, 27, 146-152. [CrossRef] [PubMed] 
94. Bedreag, O.H.; Rogobete, A.F.; Sarandan, M.; Cradigati, A.C.; Papurica, M.; Dumbuleu, M.C.; Chira, A.M.; Rosu, O.M.; Sandesc, D. Oxidative stress in severe pulmonary trauma in critical ill patients. antioxidant therapy in patients with multiple trauma-A review. Anaesthesiol. Intensive Ther. 2015, 47, 351-359. [CrossRef] [PubMed]

95. Lang, J.D.; McArdle, P.J.; O’Reilly, P.J.; Matalon, S. Oxidant-antioxidant balance in acute lung injury. Chest 2002, 122 (Suppl. 6), 314S-320S. [CrossRef] [PubMed]

96. Herridge, M.S.; Tansey, C.M.; Matté, A.; Tomlinson, G.; Diaz-Granados, N.; Cooper, A.; Guest, C.B.; Mazer, C.D.; Mehta, S.; Stewart, T.E.; et al. Functional disability 5 years after acute respiratory distress syndrome. N. Engl. J. Med. 2011, 364, 1293-1304. [CrossRef] [PubMed]

97. Kogan, A.; Segel, M.; Levin, S.; Sternik, L.; Raanani, E. Incidence of ards following cardiac surgery: Comparison between american-european consensus conference definition and berlin definition. J. Cardiothorac. Vasc. Anesth. 2017, 31, S79-S80. [CrossRef]

98. Ng, C.S.; Wan, S.; Yim, A.P.; Arifi, A.A. Pulmonary dysfunction after cardiac surgery. CHEST J. 2002, 121, 1269-1277. [CrossRef]

99. Stephens, R.S.; Shah, A.S.; Whitman, G.J.R. Lung injury and acute respiratory distress syndrome after cardiac surgery. Ann. Thorac. Surg. 2013, 95, 1122-1129. [CrossRef] [PubMed]

100. Wynne, R.; Botti, M. Postoperative pulmonary dysfunction in adults after cardiac surgery with cardiopulmonary bypass: Clinical significance and implications for practice. Am. J. Crit. Care 2004, 13, 384-393. [PubMed]

101. Fisher, B.J.; Kraskauskas, D.; Martin, E.J.; Farkas, D.; Wegelin, J.A.; Brophy, D.; Ward, K.R.; Voelkel, N.F.; Fowler, A.A.; Natarajan, R. Mechanisms of attenuation of abdominal sepsis induced acute lung injury by ascorbic acid. Am. J. Physiol. Lung Cell Mol. Physiol. 2012, 303, L20-L32. [CrossRef] [PubMed]

102. Li, W.; Maeda, N.; Beck, M.A. Vitamin C deficiency increases the lung pathology of influenza virus-infected gulo-/- mice. J. Nutr. 2006, 136, 2611-2616. [CrossRef] [PubMed]

103. Baltalarli, A.; Ozcan, V.; Ferda, B.; Aybek, H.; Sacar, M.; Onem, G.; Goksin, I.; Demir, S.; Zafer, T. Ascorbic Acid (Vitamin C) and Iloprost Attenuate the Lung Injury Caused by Ischemia/Reperfusion of the Lower Extremities of Rats. Ann. Vasc. Surg. 2006, 20, 49-55. [CrossRef] [PubMed]

104. Jin, X.; Su, R.; Li, R.; Song, L.; Chen, M.; Cheng, L.; Li, Z. Amelioration of particulate matter-induced oxidative damage by vitamin $C$ and quercetin in human bronchial epithelial cells. Chemosphere 2016, 144, 459-466. [CrossRef] [PubMed]

105. Gupta, I.; Ganguly, S.; Rozanas, C.R.; Stuehr, D.J.; Panda, K. Ascorbate attenuates pulmonary emphysema by inhibiting tobacco smoke and Rtp801-triggered lung protein modification and proteolysis. Proc. Natl. Acad. Sci. USA 2016, 113, E4208-E4217. [CrossRef] [PubMed]

106. Rice, T.W.; Wheeler, A.P.; Thompson, B.T.; de Boisblanc, B.P.; Steingrub, J.; Rock, P.; Hudson, L.; Hough, C.; Neff, M.; Sims, K. Enteral omega-3 fatty acid, gamma-linolenic acid, and antioxidant supplementation in acute lung injury. JAMA 2011, 306, 1574-1581. [CrossRef] [PubMed]

107. Gadek, J.E.; DeMichele, S.J.; Karlstad, M.D.; Pacht, E.R.; Donahoe, M.; Albertson, T.E.; Van Hoozen, C.; Wennberg, A.K.; Nelson, J.L.; Noursalehi, M. Effect of enteral feeding with eicosapentaenoic acid, gamma-linolenic acid, and antioxidants in patients with acute respiratory distress syndrome. enteral nutrition in ards study group. Crit. Care Med. 1999, 27, 1409-1420. [CrossRef] [PubMed]

108. Corredor, C.; Thomson, R.; Al-Subaie, N. Long-term consequences of acute kidney injury after cardiac surgery: A systematic review and meta-analysis. J. Cardiothorac. Vasc. Anesth. 2016, 30, 69-75. [CrossRef] [PubMed]

109. Shi, Q.; Hong, L.; Mu, X.; Zhang, C.; Chen, X. Meta-analysis for outcomes of acute kidney injury after cardiac surgery. Medicine 2016, 95, e5558. [CrossRef] [PubMed]

110. Ferreiro, A.; Lombardi, R. Acute kidney injury after cardiac surgery is associated with mid-term but not long-term mortality: A cohort-based study. PLoS ONE 2017, 12, e0181158. [CrossRef] [PubMed]

111. Hobson, C.E.; Yavas, S.; Segal, M.S.; Schold, J.D.; Tribble, C.G.; Layon, A.J.; Bihorac, A. Acute kidney injury is associated with increased long-term mortality after cardiothoracic surgery. Circulation 2009, 119, 2444-2453. [CrossRef] [PubMed]

112. O'Neal, J.B.; Shaw, A.D.; Billings, F.T. Acute kidney injury following cardiac surgery: Current understanding and future directions. Crit. Care 2016, 20, 187. [CrossRef] [PubMed] 
113. Pickering, J.W.; James, M.T.; Palmer, S.C. Acute kidney injury and prognosis after cardiopulmonary bypass: A meta-analysis of cohort studies. Am. J. Kidney Dis. 2015, 65, 283-293. [CrossRef] [PubMed]

114. Provenchère, S.; Plantefève, G.; Hufnagel, G.; Vicaut, E.; De Vaumas, C.; Lecharny, J.B.; Depoix, J.P.; Vrtovsnik, F.; Desmonts, J.M.; Philip, I. Renal dysfunction after cardiac surgery with normothermic cardiopulmonary bypass: Incidence, risk factors, and effect on clinical outcome. Anesth. Anal. 2003, 96, 1258-1264. [CrossRef]

115. Spargias, K.; Alexopoulos, E.; Kyrzopoulos, S.; Iokovis, P.; Greenwood, D.C.; Manginas, A.; Voudris, V.; Pavlides, G.; Buller, C.E.; Kremastinos, D.; et al. Ascorbic acid prevents contrast-mediated nephropathy in patients with renal dysfunction undergoing coronary angiography or intervention. Circulation 2004, 110, 2837-2842. [CrossRef] [PubMed]

116. Sadat, U.; Usman, A.; Gillard, J.H.; Boyle, J.R. Does ascorbic acid protect against contrast-induced acute kidney injury in patients undergoing coronary angiography: A systematic review with meta-analysis of randomized, controlled trials. J. Am. Coll. Cardiol. 2013, 62, 2167-2175. [CrossRef] [PubMed]

117. Gurm, H.; Sheta, M.A.; Nivera, N.; Tunkel, A. Vitamin C-induced oxalate nephropathy: A case report. J. Community Hosp. Intern. Med. Perspect. 2012, 2. [CrossRef] [PubMed]

118. Sunkara, V.; Pelkowski, T.D.; Dreyfus, D.; Satoskar, A. Acute Kidney Disease Due to Excessive Vitamin C Ingestion and Remote Roux-en-Y Gastric Bypass Surgery Superimposed on CKD. Am. J. Kidney Dis. 2015, 66, 721-724. [CrossRef] [PubMed]

119. Antonic, M. Effect of ascorbic acid on postoperative acute kidney injury in coronary artery bypass graft patients: A pilot study. Heart. Surg. Forum 2017, 20, E214-E218. [CrossRef] [PubMed]

120. Sever, K.; Ozbek, C.; Goktas, B.; Bas, S.; Ugurlucan, M.; Mansuroglu, D. Gastrointestinal complications after open heart surgery: Incidence and determinants of risk factors. Angiology 2014, 65, 425-429. [CrossRef] [PubMed]

121. Berger, M.M.; Berger-Gryllaki, M.; Wiesel, P.H.; Revelly, J.P.; Hurni, M.; Cayeux, C.; Tappy, L.; Chioléro, R. Intestinal absorption in patients after cardiac surgery. Crit. Care Med. 2000, 28, 2217-2223. [CrossRef] [PubMed]

122. Goldhill, D.R.; Whelpton, R.; Winyard, J.A.; Wilkinson, K.A. Gastric emptying in patients the day after cardiac surgery. Anaesthesia 1995, 50, 122-125. [CrossRef] [PubMed]

123. Chaudhry, R.; Zaki, J.; Wegner, R.; Pednekar, G.; Tse, A.; Sheinbaum, R.; Williams, G.W. Gastrointestinal complications after cardiac surgery: A nationwide population-based analysis of morbidity and mortality predictors. J. Cardiothorac. Vasc. Anesth. 2017, 31, 1268-1274. [CrossRef] [PubMed]

124. Cresci, G.; Hummell, A.C.; Raheem, S.A.; Cole, D. Nutrition intervention in the critically ill cardiothoracic patient. Nutr. Clin. Pract. 2012, 27, 323-334. [CrossRef] [PubMed]

125. Viana, F.F.; Chen, Y.; Almeida, A.A.; Baxter, H.D.; Cochrane, A.D.; Smith, J.A. Gastrointestinal complications after cardiac surgery: 10-year experience of a single Australian centre. ANZ J. Surg. 2013, 83, 651-656. [CrossRef] [PubMed]

126. Bjelakovic, G.; Nikolova, D.; Simonetti, R.G.; Gluud, C. Antioxidant supplements for preventing gastrointestinal cancers. Cochrane Database Syst. Rev. 2008, 16, CD004183. [CrossRef] [PubMed]

127. Freedman, J.E. Oxidative stress and platelets. Arterioscler. Thromb. Vasc. Biol. 2008, 28, s11-s16. [CrossRef] [PubMed]

128. Levi, M. Platelets at a crossroad of pathogenic pathways in sepsis. J. Thromb. Haemost. 2004, 2, $2094-2095$. [CrossRef] [PubMed]

129. Dyke, C.; Aronson, S.; Dietrich, W.; Hofmann, A.; Karkouti, K.; Levi, M.; Murphy, G.J.; Sellke, F.W.; Shore-Lesserson, L.; von Heymann, C. Universal definition of perioperative bleeding in adult cardiac surgery. J. Thorac. Cardiovasc. Surg. 2013, 147, 1458-1463. [CrossRef] [PubMed]

130. Kinnunen, E.M.; De Feo, M.; Reichart, D.; Tauriainen, T.; Gatti, G.; Onorati, F.; Maschietto, L.; Bancone, C.; Fiorentino, F.; Chocron, S. Incidence and prognostic impact of bleeding and transfusion after coronary surgery in low-risk patients. Transfusion 2017, 57, 178-186. [CrossRef] [PubMed]

131. Ranucci, M.; Baryshnikova, E.; Castelvecchio, S.; Pelissero, G. Surgical and Clinical Outcome Research (SCORE) Group. Major bleeding, transfusions, and anemia: The deadly triad of cardiac surgery. Ann. Thorac. Surg. 2013, 96, 478-485. [CrossRef] [PubMed] 
132. Gielen, C.; Dekkers, O.; Stijnen, T.; Schoones, J.; Brand, A.; Klautz, R.; Eikenboom, J. The effects of pre- and postoperative fibrinogen levels on blood loss after cardiac surgery: A systematic review and meta-analysis. Interact. Cardiovasc. Thorac. Surg. 2014, 18, 292-298. [CrossRef] [PubMed]

133. Dayton, P.G.; Weiner, M. Ascorbic acid and blood coagulation. Ann. N. Y. Acad. Sci. 1961, 92, $302-306$. [CrossRef] [PubMed]

134. Li, Y.D.; Ye, B.Q.; Zheng, S.X.; Wang, J.T.; Wang, J.G.; Chen, M.; Liu, J.G.; Pei, X.H.; Wang, L.J.; Lin, Z.X.; et al. NF-kappaB transcription factor p50 critically regulates tissue factor in deep vein thrombosis. J. Biol. Chem. 2009, 284, 4473-4483. [CrossRef] [PubMed]

135. Esmon, C.T. The interactions between inflammation and coagulation. Br. J. Haematol. 2005, 131, 417-430. [CrossRef] [PubMed]

136. Parahuleva, M.S.; Jung, J.; Burgazli, M.; Erdogan, A.; Parviz, B.; Hölschermann, H. Vitamin C suppresses lipopolysaccharide-induced procoagulant response of human monocyte-derived macrophages. Eur. Rev. Med. Pharmacol. Sci. 2016, 20, 2174-2182. [PubMed]

137. Tousoulis, D.; Antoniades, C.; Tountas, C.; Bosinakou, E.; Kotsopoulou, M.; Toutouzas, P.; Stefanadis, C. Vitamin $C$ affects thrombosis/fibrinolysis system and reactive hyperemia in patients with type 2 diabetes and coronary artery disease. Diabetes Care 2003, 26, 2749-2753. [CrossRef] [PubMed]

138. Kaehler, J.; Koeke, K.; Karstens, M.; Schneppenheim, R.; Meinertz, T.; Heitzer, T. Impaired capacity for acute endogenous fibrinolysis in smokers is restored by ascorbic acid. Free Radic. Biol. Med. 2008, 44, 315-321. [CrossRef] [PubMed]

139. Cooke, A.R. The role of acid in the pathogenesis of aspirin-induced gastrointestinal erosions and hemorrhage. Am. J. Dig. Dis. 1973, 18, 225-237. [CrossRef] [PubMed]

140. Kim, K.; Bae, O.N.; Koh, S.H.; Kang, S.; Lim, K.M.; Noh, J.Y.; Shin, S.; Kim, I.; Chung, J.H. High-Dose Vitamin C Injection to Cancer Patients May Promote Thrombosis Through Procoagulant Activation of Erythrocytes. Toxicol. Sci. 2015, 147, 350-359. [CrossRef] [PubMed]

141. Sadeghpour, A.; Alizadehasl, A.; Kyavar, M.; Sadeghi, T.; Moludi, J.; Gholizadeh, F.; Totonchi, Z.; Ghadrdoost, B. Impact of vitamin C supplementation on post-cardiac surgery ICU and hospital length of stay. Anesth. Pain Med. 2015, 5, e25337. [CrossRef] [PubMed]

142. Gelijns, A.C.; Moskowitz, A.J.; Acker, M.A.; Argenziano, M.; Geller, N.L.; Puskas, J.D.; Perrault, L.P.; Smith, P.K.; Kron, I.L.; Michler, R.E.; et al. Management practices and major infections after cardiac surgery. J. Am. Coll. Cardiol. 2014, 64, 372-381. [CrossRef] [PubMed]

143. Cove, M.E.; Spelman, D.W.; MacLaren, G. Infectious complications of cardiac surgery: A clinical review. J. Cardiothorac. Vasc. Anesth. 2012, 26, 1094-1100. [CrossRef] [PubMed]

144. Wendler, O.; Baghai, M. Infections post-cardiac surgery: New information during challenging times. J. Am. Coll. Cardiol. 2014, 64, 382-384. [CrossRef] [PubMed]

145. Benjamin, E.J.; Blaha, M.J.; Chiuve, S.E.; Cushman, M.; Das, S.R.; Deo, R.; de Ferranti, S.D.; Floyd, J.; Fornage, M.; Gillespie, C.; et al. Heart disease and stroke statistics-2017 update: A report from the American heart association. Circulation 2017, 135, e146-e603. [CrossRef] [PubMed]

146. Kirklin, J.K.; Pagani, F.D.; Kormos, R.L.; Stevenson, L.W.; Blume, E.D.; Myers, S.L.; Miller, M.A.; Baldwin, J.T.; Young, J.B.; Naftel, D.C. Eighth annual INTERMACS report: Special focus on framing the impact of adverse events. J. Heart Lung Transplant. 2017, 36, 1080-1086. [CrossRef] [PubMed]

147. Lampropulos, J.F.; Kim, N.; Wang, Y.; Desai, M.M.; Barreto-Filho, J.A.; Dodson, J.A.; Dries, D.L.; Mangi, A.A.; Krumholz, H.M. Trends in left ventricular assist device use and outcomes among medicare beneficiaries, 2004-2011. Open Heart 2014, 1, e000109. [CrossRef] [PubMed]

148. Bouza, E.; Hortal, J.; Muñoz, P.; Pascau, J.; Pérez, M.J.; Hiesmayr, M.; European Study Group on Nosocomial Infections; European Workgroup of Cardiothoracic Intensivists. Postoperative infections after major heart surgery and prevention of ventilator-associated pneumonia: A one-day European prevalence study (ESGNI-008). J. Hosp. Infect. 2006, 64, 224-230. [CrossRef] [PubMed]

149. He, S.; Chen, B.; Li, W.; Yan, J.; Chen, L.; Wang, X.; Xiao, Y. Ventilator-associated pneumonia after cardiac surgery: a meta-analysis and systematic review. J. Thorac. Cardiovasc. Surg. 2014, 148, 3148-3155.e5. [CrossRef] [PubMed] 
150. Hortal, J.; Muñoz, P.; Cuerpo, G.; Litvan, H.; Rosseel, P.M.; Bouza, E.; European Study Group on Nosocomial Infections; European Workgroup of Cardiothoracic Intensivists. Ventilator-associated pneumonia in patients undergoing major heart surgery: An incidence study in Europe. Crit. Care 2009, 13, R80. [CrossRef] [PubMed]

151. Ibañez, J.; Riera, M.; Amezaga, R.; Herrero, J.; Colomar, A.; Campillo-Artero, C.; de Ibarra, J.I.; Bonnin, O. Long-term mortality after pneumonia in cardiac surgery patients: A propensity-matched analysis. J. Intensive Care Med. 2016, 31, 34-40. [CrossRef] [PubMed]

152. Sheng, W.; Xing, Q.S.; Hou, W.M.; Sun, L.; Niu, Z.Z.; Lin, M.S.; Chi, Y.F. Independent risk factors for ventilator-associated pneumonia after cardiac surgery. J. Investig. Surg. 2014, 27, 256-261. [CrossRef] [PubMed]

153. Hunt, C.; Chakravorty, N.K.; Annan, G.; Habibzadeh, N.; Schorah, C.J. The clinical effects of vitamin C supplementation in elderly hospitalised patients with acute respiratory infections. Int. J. Vitam. Nutr. Res. 1994, 64, 212-219. [PubMed]

154. Hemilae, H. Vitamin C and Infections. Nutrients 2017, 9, 339. [CrossRef] [PubMed]

155. Hemilä, H.; Louhiala, P. Vitamin C for preventing and treating pneumonia. Cochrane Database Syst. Rev. 2013, 8, CD005532. [CrossRef] [PubMed]

156. Jouybar, R.; Kabgani, H.; Kamalipour, H.; Shahbazi, S.; Allahyary, E.; Rasouli, M.; Akhlagh, S.H.; Shafa, M.; Ghazinoor, M.; Moeinvaziri, M.T.; et al. The perioperative effect of ascorbic acid on inflammatory response in coronary artery bypass graft surgery; a randomized controlled trial coronary artery bypass graft surgery. Age (year) 2012, 56, 61-83.

157. Knodell, R.G.; Tate, M.A.; Akl, B.F.; Wilson, J.W. Vitamin C prophylaxis for posttransfusion hepatitis: Lack of effect in a controlled trial. Am. J. Clin. Nutr. 1981, 34, 20-23. [CrossRef] [PubMed]

158. Li, C.C. Changes of creatine phosphokinase and malondialdehyde in the serum and clinical use of large doses of vitamin C following open heart surgery. Zhonghua Wai Ke Za Zhi (Chin. J. Surg.) 1990, 28, 16-17. [PubMed]

159. Carnes, C.A.; Chung, M.K.; Nakayama, T.; Nakayama, H.; Baliga, R.S.; Piao, S.; Kanderian, A.; Pavia, S.; Hamlin, R.L.; McCarthy, P.M.; et al. Ascorbate attenuates atrial pacing-induced peroxynitrite formation and electrical remodeling and decreases the incidence of postoperative atrial fibrillation. Circ. Res. 2001, 89, e32-e38. [CrossRef] [PubMed]

160. Demirag, K.; Askar, F.Z.; Uyar, M.; Cevik, A.; Ozmen, D.; Mutaf, I.; Bayindir, O. The protective effects of high dose ascorbic acid and diltiazem on myocardial ischaemia-reperfusion injury. Middle East J. Anaesthesiol. 2001, 16, 67-79. [PubMed]

161. Eslami, M.; Badkoubeh, R.S.; Mousavi, M.; Radmehr, H.; Salehi, M.; Tavakoli, N.; Avadi, M.R. Oral ascorbic acid in combination with beta-blockers is more effective than beta-blockers alone in the prevention of atrial fibrillation after coronary artery bypass grafting. Tex. Heart Inst. J. 2007, 342, 68.

162. Colby, J.A.; Chen, W.T.; Baker, W.L.; Coleman, C.I.; Reinhart, K.; Kluger, J.; White, C.M. Effect of ascorbic acid on inflammatory markers after cardiothoracic surgery. Am. J. Health Syst. Pharm. 2011, 68, 1632-1639. [CrossRef] [PubMed]

163. Papoulidis, P.; Ananiadou, O.; Chalvatzoulis, E.; Ampatzidou, F.; Koutsogiannidis, C.; Karaiskos, T.; Madesis, A.; Drossos, G. The role of ascorbic acid in the prevention of atrial fibrillation after elective on-pump myocardial revascularization surgery: A single-center experience-a pilot study. Interact. Cardiovasc. Thorac. Surg. 2011, 12, 121-124. [CrossRef] [PubMed]

164. Bjordahl, P.M.; Helmer, S.D.; Gosnell, D.J.; Wemmer, G.E.; O'Hara, W.W.; Milfeld, D.J. Perioperative supplementation with ascorbic acid does not prevent atrial fibrillation in coronary artery bypass graft patients. Am. J. Surg. 2012, 204, 862-867. [CrossRef] [PubMed]

165. Dehghani, M.R.; Majidi, N.; Rahmani, A.; Asgari, B.; Rezaei, Y. Effect of oral vitamin C on atrial fibrillation development after isolated coronary artery bypass grafting surgery: A prospective randomized clinical trial. Cardiol. J. 2014, 21, 492-499. [CrossRef] [PubMed]

166. Ebade, A.; Taha, W.S.; Saleh, R.H.; Fawzy, A. Ascorbic acid versus magnesium for the prevention of atrial fibrillation after coronary artery bypass grafting surgery. Egypt. J. Cardiothorac. Anesth. 2014, 8, 59-65. [CrossRef] 
167. Samadikhah, J.; Golzari, S.E.J.; Sabermarouf, B.; Karimzadeh, I.; Tizro, P.; Khanli, H.M.; Ghabili, K. Efficacy of Combination Therapy of Statin and Vitamin C in Comparison with Statin in the Prevention of Post-CABG Atrial Fibrillation. Adv. Pharm. Bull. 2014, 4, 97. [PubMed]

168. Das, D.; Sen, C.; Goswami, A. Effect of Vitamin C on adrenal suppression by etomidate induction in patients undergoing cardiac surgery: A randomized controlled trial. Ann. Card. Anaesth. 2016, 19, 410. [CrossRef] [PubMed]

169. Antonic, M.; Lipovec, R.; Gregorcic, F.; Juric, P.; Kosir, G. Perioperative ascorbic acid supplementation does not reduce the incidence of postoperative atrial fibrillation in on-pump coronary artery bypass graft patients. J. Cardiol. 2017, 69, 98-102. [CrossRef] [PubMed]

170. Crimi, E.; Sica, V.; Williams-Ignarro, S.; Zhang, H.; Slutsky, A.S.; Ignarro, L.J.; Napoli, C. The role of oxidative stress in adult critical care. Free Radic. Biol. Med. 2006, 40, 398-406. [CrossRef] [PubMed]

171. Howe, K.P.; Clochesy, J.M.; Goldstein, L.S.; Owen, H. Mechanical ventilation antioxidant trial. Am. J. Crit. Care 2015, 24, 440-445. [CrossRef] [PubMed]

172. Barta, E.; Pechán, I.; Cornák, V.; Luknárová, O.; Rendeková, V.; Verchovodko, P. Protective effect of alpha-tocopherol and L-ascorbic acid against the ischemic-reperfusion injury in patients during open-heart surgery. Bratisl. Lek. Listy 1991, 92, 174-183. [PubMed]

173. Angdin, M.; Settergren, G.; Starkopf, J.; Zilmer, M.; Zilmer, K.; Vaage, J. Protective effect of antioxidants on pulmonary endothelial function after cardiopulmonary bypass. J. Cardiothorac. Vasc. Anesth. 2003, 17, 314-320. [CrossRef]

174. Gunes, T.; Bozok, S.; Kestelli, M.; Yurekli, I.; Ilhan, G.; Ozpak, B.; Bademci, M.; Ozcem, B.; Sahin, A. $\alpha$-tocopherol and ascorbic acid in early postoperative period of cardiopulmonary bypass. J. Cardiovasc. Med. 2012, 13, 691-699. [CrossRef] [PubMed]

175. Westhuyzen, J.; Cochrane, A.D.; Tesar, P.J.; Mau, T.; Cross, D.B.; Frenneaux, M.P.; Khafagi, F.A.; Fleming, S.J. Effect of preoperative supplementation with alpha-tocopherol and ascorbic acid on myocardial injury in patients undergoing cardiac operations. J. Thorac. Cardiovasc. Surg. 1997, 113, 942-948. [CrossRef]

176. Castillo, R.; Rodrigo, R.; Perez, F.; Cereceda, M.; Asenjo, R.; Zamorano, J.; Navarrete, R.; Villalabeitia, E.; Sanz, J.; Baeza, C. Antioxidant therapy reduces oxidative and inflammatory tissue damage in patients subjected to cardiac surgery with extracorporeal circulation. Basic Clin. Pharmacol. Toxicol. 2011, 108, 256-262. [CrossRef] [PubMed]

177. Rodrigo, R.; Prieto, J.C.; Castillo, R. Cardioprotection against ischaemia/reperfusion by vitamins C and E plus n-3 fatty acids: Molecular mechanisms and potential clinical applications. Clin. Sci. 2013, 124, 1-15. [CrossRef] [PubMed]

178. Stanger, O.; Aigner, I.; Schimetta, W.; Wonisch, W. Antioxidant supplementation attenuates oxidative stress in patients undergoing coronary artery bypass graft surgery. Tohoku J. Exp. Med. 2014, 232, 145-154. [CrossRef] [PubMed]

179. Sartor, Z.; Kesey, J.; Dissanaike, S. The effects of intravenous vitamin C on point-of-care glucose monitoring. J. Burn Care Res. 2015, 36, 50-56. [CrossRef] [PubMed]

180. Vasudevan, S.; Hirsch, I.B. Interference of intravenous vitamin C with blood glucose testing. Diabetes Care 2014, 37, e93-e94. [CrossRef] [PubMed]

181. Halliwell, B. Vitamin C: Antioxidant or pro-oxidant in vivo? Free Radic. Res. 1996, 25, 439-454. [CrossRef] [PubMed]

182. Gey, K.F. Vitamins $E$ plus $C$ and interacting conutrients required for optimal health. A critical and constructive review of epidemiology and supplementation data regarding cardiovascular disease and cancer. BioFactors 1998, 7, 113-174. [PubMed]

183. Bucala, R. Lipid and lipoprotein oxidation: Basic mechanisms and unresolved questions in vivo. Redox Rep. 1996, 2, 291-307. [CrossRef] [PubMed]

184. Chen, Q.; Espey, M.G.; Krishna, M.C.; Mitchell, J.B.; Corpe, C.P.; Buettner, G.R.; Shacter, E.; Levine, M. Pharmacologic ascorbic acid concentrations selectively kill cancer cells: Action as a pro-drug to deliver hydrogen peroxide to tissues. Proc. Natl. Acad. Sci. USA 2005, 102, 13604-13609. [CrossRef] [PubMed]

185. Collins, A.; Cadet, J.; Epe, B.; Gedik, C. Problems in the measurement of 8-oxoguanine in human DNA. Report of a workshop, DNA oxidation, held in Aberdeen, UK, 19-21 January, 1997. Carcinogenesis 1997, 18, 1833-1836. [CrossRef] [PubMed] 
186. Rümelin, A.; Jaehde, U.; Kerz, T.; Roth, W.; Krämer, M.; Fauth, U. Early postoperative substitution procedure of the antioxidant ascorbic acid. J. Nutr. Biochem. 2005, 16, 104-108. [CrossRef] [PubMed]

187. Rümelin, A.; Humbert, T.; Lühker, O.; Drescher, A.; Fauth, U. Metabolic clearance of the antioxidant ascorbic acid in surgical patients. J. Surg. Res. 2005, 129, 46-51. [CrossRef] [PubMed]

188. Bjugstad, K.B.; Rael, L.T.; Stewart Levy, S.; Carrick, M.; Mains, C.W.; Slone, D.S.; Bar-Or, D. Oxidation-reduction potential as a biomarker for severity and acute outcome in traumatic brain injury. Oxid. Med. Cell. Longev. 2016. [CrossRef] [PubMed]

189. Rael, L.T.; Bar-Or, R.; Salottolo, K.; Mains, C.W.; Slone, D.S.; Offner, P.J.; Bar-Or, D. Injury severity and serum amyloid a correlate with plasma oxidation-reduction potential in multi-trauma patients: A retrospective analysis. Scand. J. Trauma Resusc. Emerg. Med. 2009. [CrossRef] [PubMed]

190. Robitaille, L.; Hoffer, L.J. A simple method for plasma total vitamin C analysis suitable for routine clinical laboratory use. Nutr. J. 2015, 15, 40. [CrossRef] [PubMed]

191. Pullar, J.M.; Bayer, S.; Carr, A.C. Appropriate handling, processing and analysis of blood samples is essential to avoid oxidation of vitamin $C$ to dehydroascorbic acid. Antioxidants 2018, 7, 29. [CrossRef] [PubMed]

192. Key, T.; Oakes, S.; Davey, G.; Moore, J.; Edmond, L.M.; McLoone, U.J.; Thurnham, D.I. Stability of vitamins a, c, and e, carotenoids, lipids, and testosterone in whole blood stored at 4 degrees c for 6 and $24 \mathrm{~h}$ before separation of serum and plasma. Cancer Epidemiol. Biomark. Prev. 1996, 5, 811-814.

193. Wang, Y.; Liu, X.J.; Robitaille, L.; Eintracht, S.; MacNamara, E.; Hoffer, L.J. Effects of vitamin C and vitamin d administration on mood and distress in acutely hospitalized patients. Am. J. Clin. Nutr. 2013, 98, 705-711. [CrossRef] [PubMed]

194. Margolis, S.A.; Duewer, D.L. Measurement of ascorbic acid in human plasma and serum: Stability, intralaboratory repeatability, and interlaboratory reproducibility. Clin. Chem. 1996, 42, 1257-1262. [PubMed]

195. Kirkham, J.J.; Dwan, K.M.; Altman, D.G.; Gamble, C.; Dodd, S.; Smyth, R.; Williamson, P.R. The impact of outcome reporting bias in randomised controlled trials on a cohort of systematic reviews. BMJ 2010, 340, c365. [CrossRef] [PubMed]

(C) 2018 by the authors. Licensee MDPI, Basel, Switzerland. This article is an open access article distributed under the terms and conditions of the Creative Commons Attribution (CC BY) license (http:/ / creativecommons.org/licenses/by/4.0/). 